\title{
Glass groups, glass supply and recycling in late Roman Carthage
}

\author{
Nadine Schibille $^{1,2} \cdot$ Allison Sterrett-Krause $^{3} \cdot$ Ian C. Freestone $^{1}$
}

Received: 15 January 2016/Accepted: 1 February 2016/Published online: 7 March 2016

(C) The Author(s) 2016. This article is published with open access at Springerlink.com

\begin{abstract}
Carthage played an important role in maritime exchange networks during the Roman and late antique periods. One hundred ten glass fragments dating to the third to sixth centuries CE from a secondary deposit at the Yasmina Necropolis in Carthage have been analysed by electron microprobe analysis (EPMA) to characterise the supply of glass to the city. Detailed bivariate and multivariate data analysis identified different primary glass groups and revealed evidence of extensive recycling. Roman mixed antimony and manganese glasses with $\mathrm{MnO}$ contents in excess of 250 ppm were clearly the product of recycling, while iron, potassium and phosphorus oxides were frequent contaminants. Primary glass sources were discriminated using $\mathrm{TiO}_{2}$ as a proxy for heavy minerals (ilmenite/spinel), $\mathrm{Al}_{2} \mathrm{O}_{3}$ for feldspar and $\mathrm{SiO}_{2}$ for quartz in the glassmaking sands. It was thus possible to draw conclusions about the chronological and geographical attributions of the primary glass types. Throughout much of the period covered in this study, glassworkers in Carthage utilised glass from both Egyptian and Levantine sources. Based on their geochemical
\end{abstract}

Electronic supplementary material The online version of this article (doi:10.1007/s12520-016-0316-1) contains supplementary material, which is available to authorized users.

Nadine Schibille

nadine.schibille@cnrs-orleans.fr

$\triangle$ Ian C. Freestone

i.freestone@ucl.ac.uk

1 Institute of Archaeology, UCL, 31-34 Gordon Square, London WC1H OPY, UK

2 IRAMAT-CEB, UMR 5060, CNRS/Université d'Orléans, 3D rue de la Férollerie, 45071 Orléans, France

3 Department of Classics, College of Charleston, 66 George Street, Charleston, SC 29424, USA characteristics, we conclude that Roman antimony and Roman manganese glasses originated from Egypt and the Levant, respectively, and were more or less simultaneously worked at Carthage in the fourth century as attested by their mixed recycling (Roman Sb-Mn). In the later fourth and early fifth centuries, glasses from Egypt (HIMT) and the Levant (two Levantine I groups) continued to be imported to Carthage, although the Egyptian HIMT is less well represented at Yasmina than in many other late antique glass assemblages. In contrast, in the later fifth and sixth centuries, glass seems to have been almost exclusively sourced from Egypt in the form of a manganese-decolourised glass originally described and characterised by Foy and colleagues (2003). Hence, the Yasmina assemblage testifies to significant fluctuations in the supply of glass to Carthage that require further attention.

Keywords Carthage $\cdot$ Primary glass groups $\cdot$ Electron microprobe $\cdot$ HIMT $\cdot$ Recycling $\cdot$ Egyptian glass $\cdot$ Levantine glass

\section{Introduction}

The growing body of data on glass assemblages paints an increasingly complex picture of the chronological and geographical distribution patterns of the prevalent glass groups. Based mainly on differences in the alumina, lime and iron oxide contents, a number of natron-type glasses have been identified that dominate the archaeological record in the Mediterranean and Europe for most of the first millennium $\mathrm{CE}$ and that are thought to have been produced either on the Levantine coast (Levantine I and II, some Roman groups) or in Egypt (Egypt I and II, high iron, manganese and titanium glass (HIMT; Foy et al. 2003; Freestone et al. 2000; Gratuze and Barrandon 1990). These main glass groups can be further 
divided into sub-types on grounds of their minor and trace element characteristics (e.g. Foster and Jackson 2010; Freestone 2005; Foy et al. 2003; Jackson and Paynter 2015; Picon and Vichy 2003; Rosenow and Rehren 2014; ThirionMerle et al. 2003). Primary production sites for Levantine I (sixth to seventh centuries) and Levantine II (seventh to eighth centuries) glass have been identified (Gorin-Rosen 1995; Gorin-Rosen 2000; Tal et al. 2004); the primary production sites of Egypt I and II, Roman and HIMT glasses are still unknown (Nenna 2014). It has been inferred from circumstantial evidence, along with isotopic data which point to an eastern Mediterranean origin (Ganio et al. 2012, Brems et al. 2013), that most Roman green-blue glass of the first to fourth centuries originated on the Levantine coast and that HIMT was produced in northern Egypt.

Despite the increasing volume of analytical data, there is a near-complete lack of information about the trade routes that linked the production centres to consumer sites around the Mediterranean and Europe. Greiff and Hartmann recently observed systematic differences in the supply of primary glass between the eastern Mediterranean, central Europe and the British Isles during the fifth to seventh centuries CE (Greiff and Hartmann 2013; but see also e.g. Ceglia et al. 2015; Foy et al. 2003; Picon and Vichy 2003; Freestone et al. 2000, 2002a; Ganio et al. 2012; Nenna 2014). Their study exposed a conspicuous absence of several glass types (Levantine I, Egypt I and II) in central Europe north of the Alps, where Roman glass appears to have been replaced by a single glass type similar to HIMT. All other geographical regions, including the eastern Mediterranean, Italy and the British Isles showed a considerable presence of Levantine alongside HIMT glass (Greiff and Hartmann 2013). According to the authors, this difference suggests divergent supply routes between the production sites of HIMT and Levantine I glass and central and northwestern Europe. In order to shed further light on these developments, it is necessary to consider the role of northern Africa within the Mediterranean trade networks during the Roman and late antique periods (see Gliozzo et al. 2013 for a Roman assemblage from Morocco).

By conducting the first comprehensive analytical study of late Roman and early medieval glass from Carthage in the Roman province of Africa Proconsularis, our objective was to add an important piece to the jigsaw. The city of Carthage was built on the northeastern promontory of modern day Tunis and ranks amongst the most important cities in the ancient Mediterranean, second only to Rome and supplier of natural resources and goods to the Roman capital for most of the city's Roman history. Carthage's strategic position and extensive artificial harbour contributed to the city's prosperity, particularly during the later Roman period and even beyond the Vandal conquest of 439 CE (von Rummel 2011; Wickham 2005, pp. 87-91, 708-741). Not much is known about Carthage's fortunes during late antiquity or, in fact, the impact of the Vandal invasion on the city's economy and trade. Imported ceramics from the eastern Mediterranean, particularly amphorae types associated with Syro-Palestine, Egypt and Asia Minor, increased dramatically during the second half of the fifth century, suggesting changes in the city's seaborne connectivity (Fulford 1980; Merrills and Miles 2010, pp. 141-176; von Rummel 2011; Wickham 2005, pp. 708-712). Evidence from ceramics and coinage indicates a certain stagnation and subsequent decrease in overseas commercial activities following the Byzantine re-conquest towards the end of the sixth century (Fulford 1980). After the Umayyad conquest in $698 \mathrm{CE}$, the once prosperous city gradually fell into decay, even though there is some evidence that the ports were not completely deserted in the following centuries (Hurst 2010).

Carthaginian excavations regularly yield sizeable glass assemblages, suggesting a continuous influx of raw glass from the eastern Mediterranean throughout the Roman, Vandal and Byzantine periods (e.g. Fünfschilling 1999; Goldstein and Lindgren 2005; Hayes 1993; Schmidt 2007; Sterrett-Krause 2009; Tatton-Brown 1984; for raw glass from Carthage, see e.g. Freestone 1994; Tatton-Brown 1994). This article presents new analytical data for late antique glass from Carthage and explores the range and scale of the supply of raw glass to the city and its changes during this important transitional period. We have carried out a systematic categorisation of the different glass types recovered from the Yasmina Necropolis excavated between 1992 and 1997 under the direction of Naomi Norman of the University of Georgia (USA). The extramural cemetery was located just south of the Theodosian city walls and the Circus in the southwestern quadrant of the ancient city of Carthage, in the modern suburb of Yasmina (UTM 32S $616997 \mathrm{mE} 4078858 \mathrm{mN}$ ) (Fig. 1). The burial ground extends beyond the area of excavation; it contains a wide variety of burial and monument types dating from the late first to the sixth centuries CE (Annabi 1992; Norman 2002; Norman 2003; Norman and Haeckl 1993). While the presence of substantial amounts of glass waste and chunks of raw glass amongst the finds points to the existence of an active secondary glassworking tradition at Carthage during this time, the various types of raw glass identified provide crucial data for assessing the nature of the economic activities and the continuity of maritime trade in context of political fragmentation towards the end of the western Roman Empire.

\section{Materials and methods}

Of approximately 2100 glass fragments recovered in the excavations at Yasmina, about 360 diagnostic pieces (rims, bases, handles) from the northern part of the site were initially chosen for typological study (Sterrett-Krause 2006, 2009). Virtually all of the glass fragments were found in late sixthor early seventh-century landfilling layers that covered the 
Fig. 1 Map of Carthage showing the location of the Yasmina Necropolis in relation to Roman public monuments

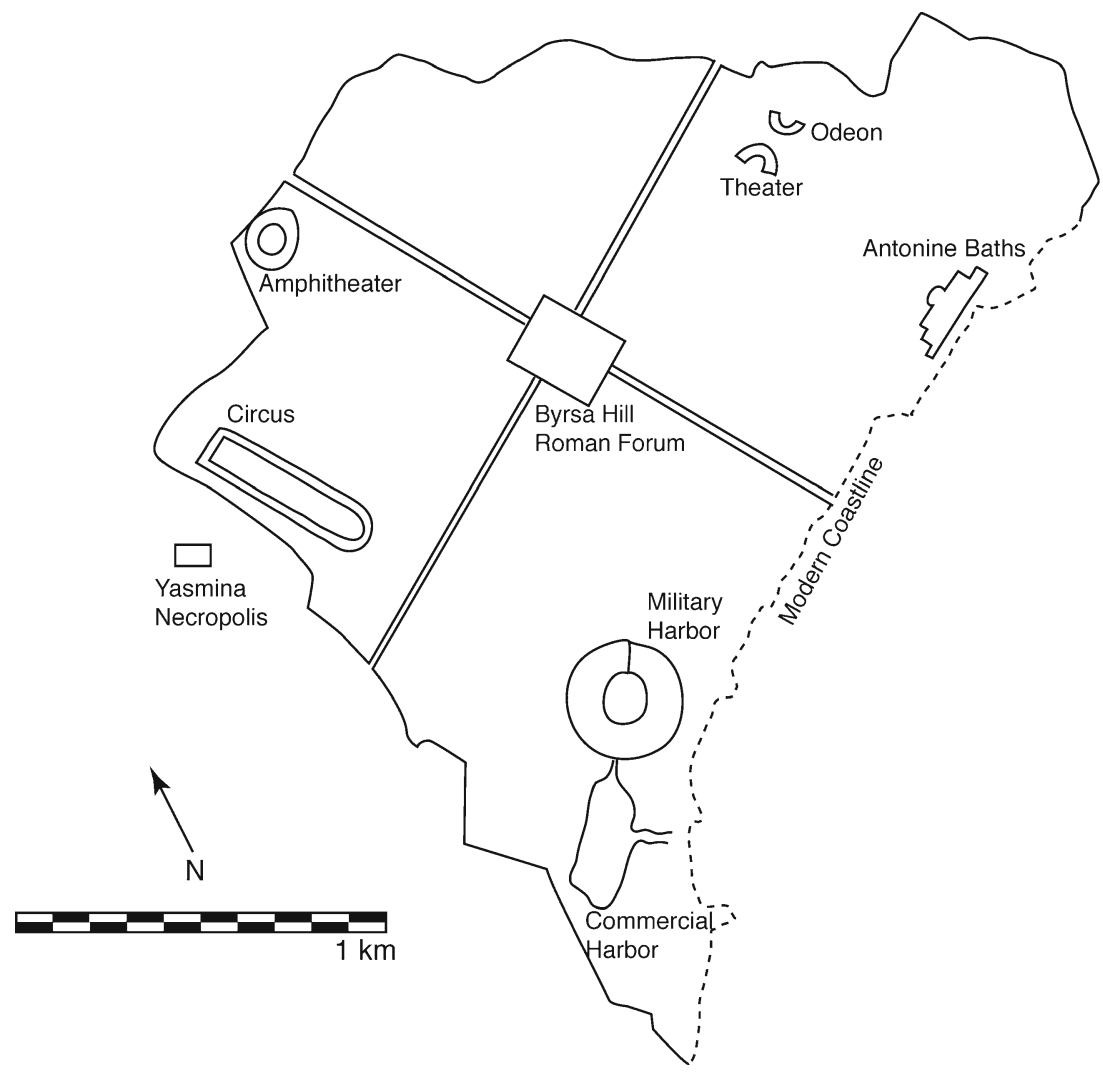

burial ground, converting the area to other uses (Norman 2002; Norman and Haeckl 1993; Sterrett-Krause 2006). Thus, very few objects could be dated based on stratigraphic relationships. Most of the vessels were simple blown forms of long duration; the few types that can be closely dated are of a third- to fifth-century date. The majority of the glass probably dates to the third to fourth century, while the identifiable fifthcentury forms such as goblets and lamps are relatively rare (Sterrett-Krause 2006, 2009).

A total of 110 out of the 360 catalogued fragments were selected for quantitative electron microprobe analysis (EPMA). Since the glass was almost exclusively found in secondary deposition contexts, the stratigraphic context was not considered a viable basis for sampling, samples for analysis were instead chosen on the basis of typology and visual colour. Several fragments represented each category of vessels identified at the site such as rims of beakers, dishes and flasks (30 samples), diverse vessel bases (34 samples), stems (2) and lamp handles (2). The selection also includes a group of flat bases (14), which were hypothesised as part of the output of a single secondary workshop (Sterrett-Krause 2009) (Fig. 2). Visually, the vessel fragments display various pale shades of olive green to natural blue-green (aqua), only very few samples appeared to be more or less colourless. Additionally, 11 black bracelets were selected as well as the entire range of glassworking debris: small chunks of unworked glass, drips, blobs, malformed vessels and moils (waste glass knocked off the blowpipe after completing a vessel). These glassworking remains are visually similar in colour to the vessels in the assemblage: bluish green, green and colourless. The set of samples drawn from the glass finds for scientific analyses therefore represents a comprehensive crosssection of the whole range of artefacts (forms and types) and colours exhibited by the Yasmina assemblage as a whole.

Small fragments of glass were mounted in epoxy resin blocks, polished down to $0.25 \mu \mathrm{m}$ and vacuumcoated with carbon. They were analysed using a JEOL JXA 8100 microprobe with three wavelength dispersive spectrometers, operated at $15-\mathrm{kV}$ accelerating potential, beam current $50 \mathrm{nA}$, working distance of $10 \mathrm{~mm}$ and rastered at a magnification of $\times 800$. X-rays were collected for $30 \mathrm{~s}$ on peak and $10 \mathrm{~s}$ on each background. Standards were pure elements, oxides and minerals of known composition. Seven areas were analysed on each sample and the mean taken. Corning Museum Ancient Glass Standards A and B (Brill 1999) were measured eight times during the same analytical run, and results compare well with the given values (Table 1) with agreement typically better than $20 \%$ relative for absolute concentrations in excess of 0.1 and $5 \%$ relative for concentrations in excess of $0.5 \%$. Some of our 

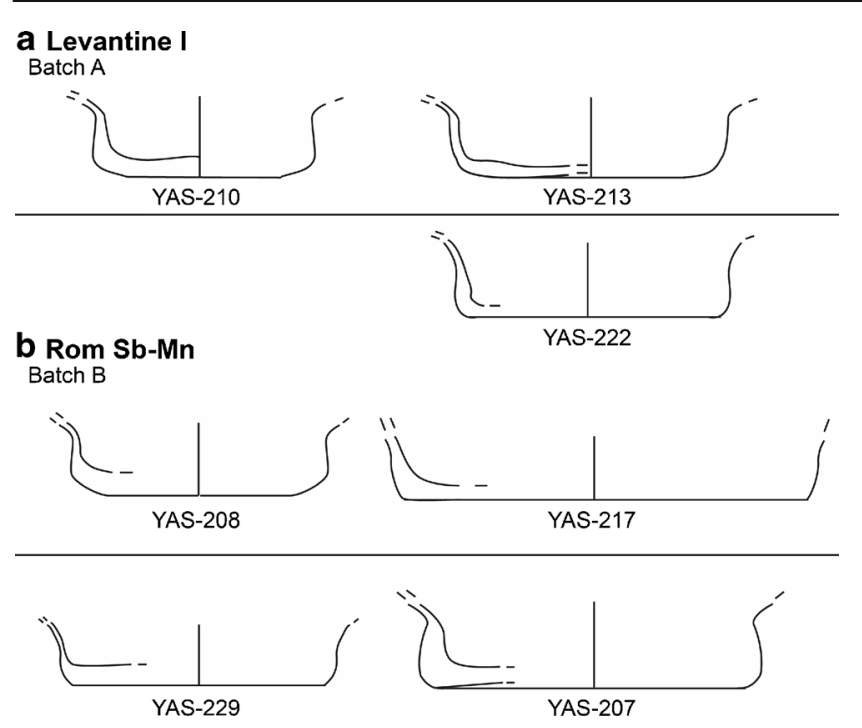

C Rom Sb Batch C

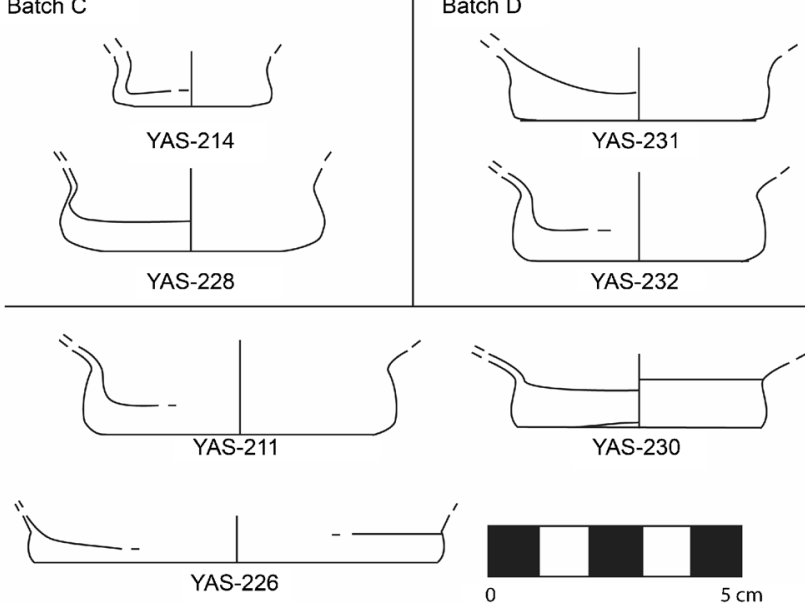

Fig. 2 Fourteen vessel bases tentatively attributed to a single Carthaginian workshop separated according to compositional groups. a Levantine I glass and Batch A (top); b Rom Sb-Mn samples and Batch B (top); c Rom-Sb with Batch C (top left) and Batch D (top right)

discussion depends upon our ability to analyse $\mathrm{MnO}$ at levels down to $0.02 \%$. A comparison of data on sodalime-silica collected under the same analytical conditions with solution ICP-MS data confirms that this is indeed the case, as is shown in the supplementary material.

To identify compositional groups and to reveal relationships among the Yasmina assemblage, principal component analysis (PCA) was performed on eight of the major and minor base glass elements $\left(\mathrm{SiO}_{2}, \mathrm{Na}_{2} \mathrm{O}, \mathrm{CaO}, \mathrm{Al}_{2} \mathrm{O}_{3}, \mathrm{FeO}, \mathrm{TiO}_{2}\right.$, $\mathrm{MgO}$ and $\mathrm{K}_{2} \mathrm{O}$ ) using Matlab R2011a (v.7.12.0) for Mac OS $\mathrm{X}$ (v.10.7.5). PCA was computed directly on the EPMA data matrix scaled to the column means. The scores of principal components 1 and 2 with eigenvalues of $>1 \quad(\mathrm{PC} 1=3.64$; PC2 $=2.47$ ) were plotted alongside the eight variables represented by vectors (Fig. 3). The compositional data were also analysed by binary plots to illustrate mixing behaviour and to identify group structures.

\section{Results}

As anticipated from the archaeological chronology, all but two of the samples analysed are natron-type soda-lime-silica glasses with low magnesia and potash, typical of the Mediterranean and European regions in the first millennium $\mathrm{CE}$, prior to around $800 \mathrm{CE}$ (Table 1). Despite the elevated $\mathrm{MgO}$ and/or $\mathrm{K}_{2} \mathrm{O}$ of the two remaining samples (YAS-332, YAS-337C), we believe that the base glass of these also had natron as a primary flux (see below). An iterative process of data inspection that involved plotting and re-plotting, and the comparison of the chemical data with previously recognised categories, has allowed us to attribute the bulk of the material to six main primary production groups, with a further compositional group due to secondary recycling and another owing to colouration with iron, along with several outliers. The main primary production groups are easily distinguished in the principal component analysis (Fig. 3). The variance of the first two principal components based upon the concentrations of the eight major and minor base glass elements corresponds to $76 \%$ of the total variance of the original dataset. The length and direction of the vector show the contribution of each element (variable) to the two principal components. Principal component 1 has positive coefficients for $\mathrm{CaO}, \mathrm{Al}_{2} \mathrm{O}_{3}, \mathrm{FeO}$, $\mathrm{TiO}_{2}, \mathrm{MgO}$ and $\mathrm{K}_{2} \mathrm{O}$, while principal component 2 is positively correlated particularly with $\mathrm{Na}_{2} \mathrm{O}$ and to a lesser extent with $\mathrm{FeO}, \mathrm{TiO}_{2}$ and $\mathrm{MgO}$. The six main primary production groups are separated by differing amounts of $\mathrm{Na}_{2} \mathrm{O}$ added as flux as well as by the elements $\mathrm{TiO}_{2}, \mathrm{FeO}$ and $\mathrm{MgO}$, reflecting variations in the heavy mineral content of the glassmaking sands, and $\mathrm{Al}_{2} \mathrm{O}_{3}$ and $\mathrm{CaO}$, indicative of the less dense sand components, feldspar and lime (shell). It is argued below that one group (Lev I-high $\mathrm{MgO}$ ) is a sub-group of Levantine I and originated from the same source. A group of 11 black glass bangles deliberately coloured by $3-10 \% \mathrm{FeO}$ have been excluded from the multivariate statistical treatment to render data analysis more straightforward and to ensure comparability. These glass bangles are discussed separately below.

\section{Roman antimony-decolourised glass}

The Roman antimony-decolourised glasses have antimony oxide concentrations ranging from 0.3 to $0.8 \%$ and correspond to the $S b$ group of Jackson and Paynter (2015). Membership of this group is restricted to glass with $\mathrm{MnO}$ contents of less than $0.025 \%$, for reasons discussed below. As indicated by the PCA (Fig. 3), the Roman antimonydecolourised (Rom-Sb) glasses have on average the highest levels of soda in the assemblage and comparatively low lime, 


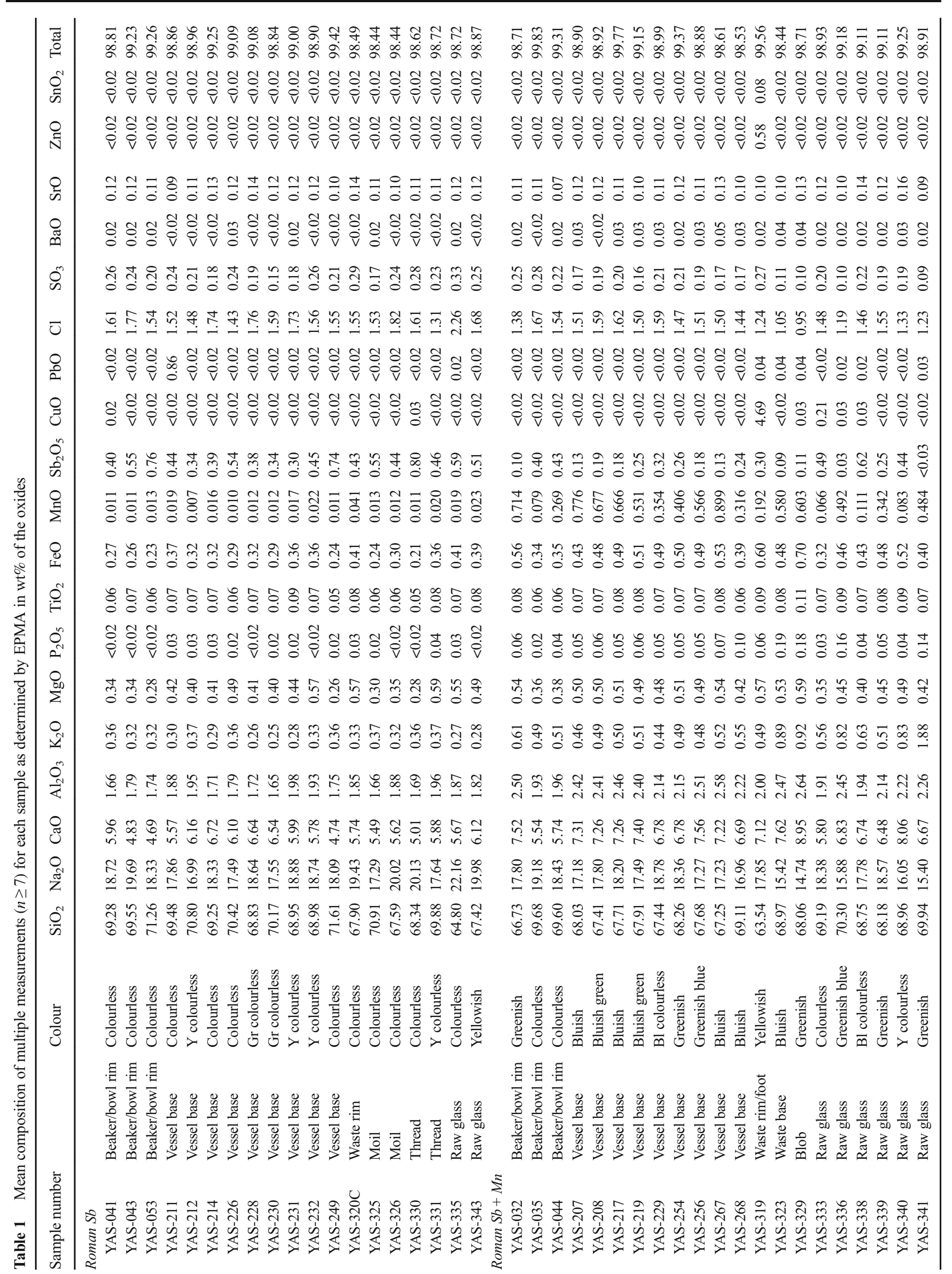




\begin{tabular}{|c|c|c|c|c|}
\hline & $\underset{\alpha}{\infty}$ & 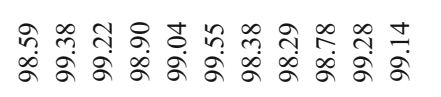 & 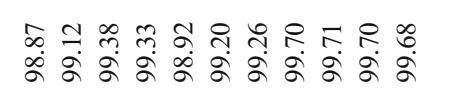 & 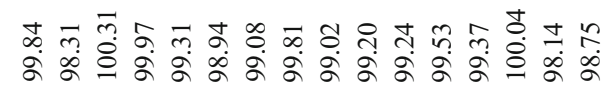 \\
\hline & $\stackrel{\tilde{\sigma}}{\dot{v}}$ & 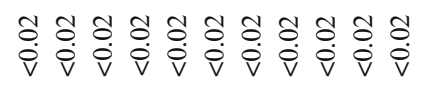 & 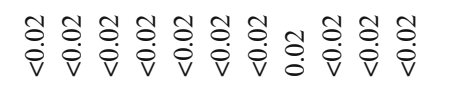 & 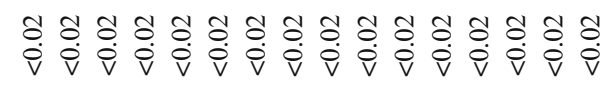 \\
\hline & $\stackrel{\leftrightarrow}{\dot{\nabla}}$ & 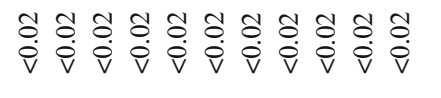 & 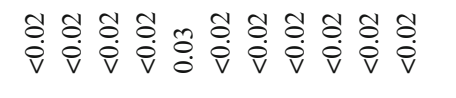 & 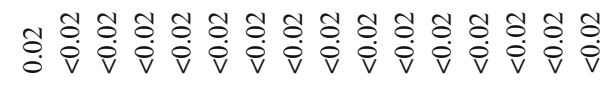 \\
\hline & $\stackrel{8}{\circ}$ & 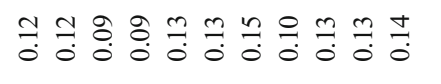 & 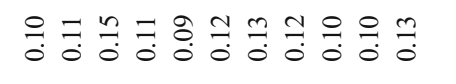 & 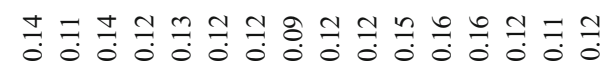 \\
\hline & $\stackrel{\wp}{\circ}$ & 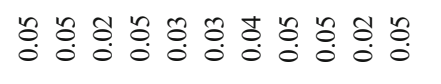 & むั & 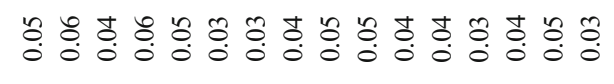 \\
\hline & $\stackrel{\circ}{\circ}$ & ‡: & 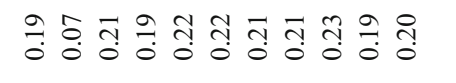 & 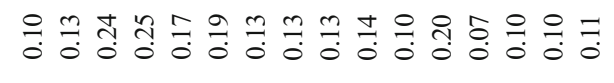 \\
\hline & 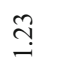 & ஸి & 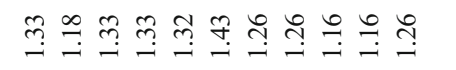 & 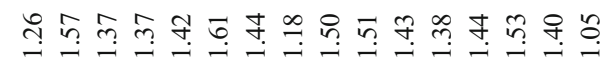 \\
\hline & & 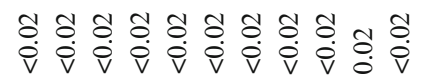 & 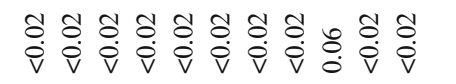 & 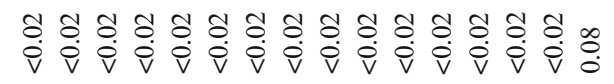 \\
\hline & & 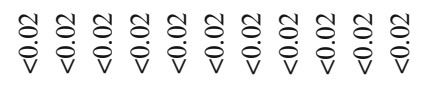 & 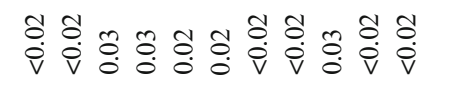 & 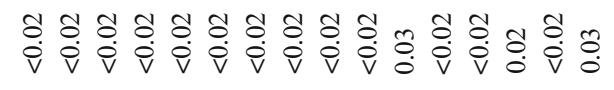 \\
\hline & & 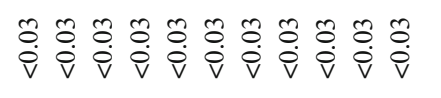 & 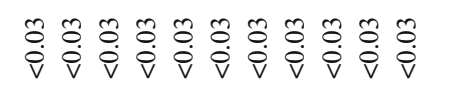 & 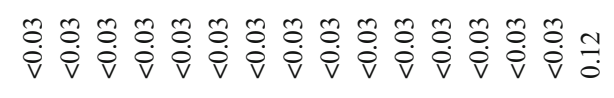 \\
\hline & & 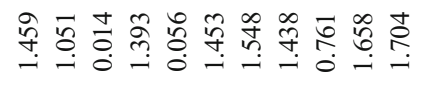 & 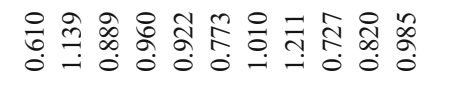 & 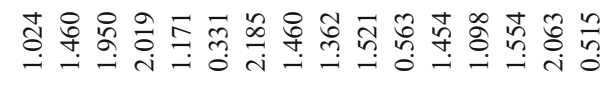 \\
\hline & $\stackrel{\infty}{\circ}$ & 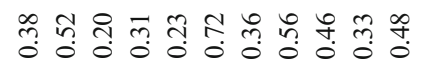 & 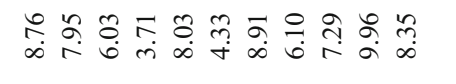 & 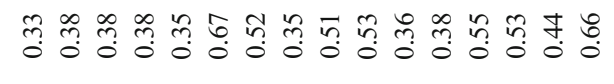 \\
\hline & oे & 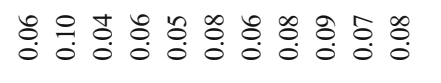 & 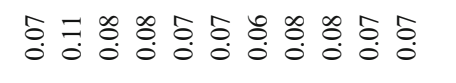 & : \\
\hline & $\begin{array}{ll}0 \\
0 \\
0\end{array}$ & 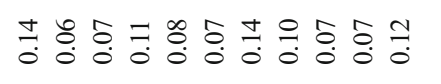 & 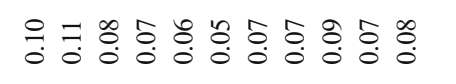 & 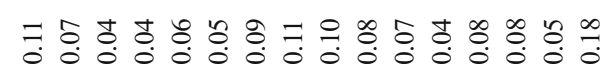 \\
\hline & $\stackrel{\infty}{0}$ & है & 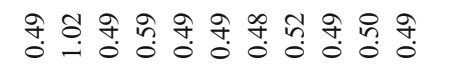 & 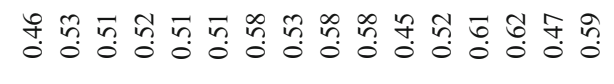 \\
\hline & i & 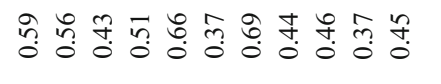 & 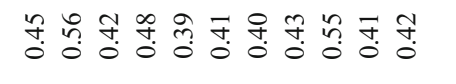 & 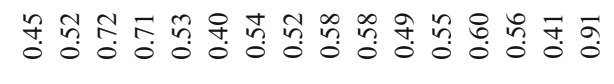 \\
\hline & $\overline{\mathrm{n}}$ & 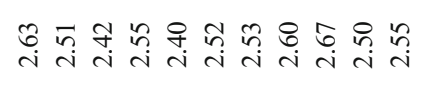 & 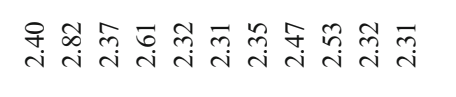 & 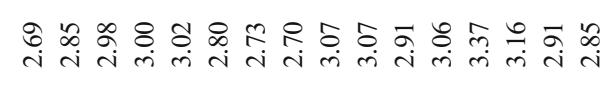 \\
\hline & $\stackrel{n}{r}$ & 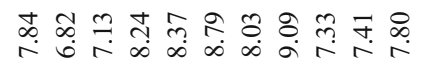 & 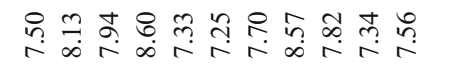 & 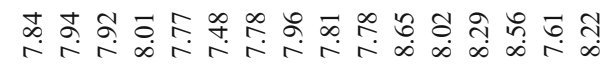 \\
\hline & $\stackrel{n}{\curvearrowleft}$ & 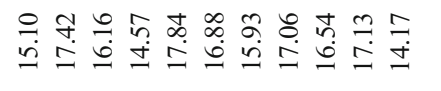 & 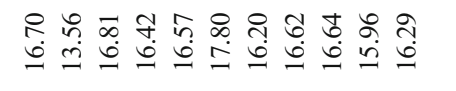 & 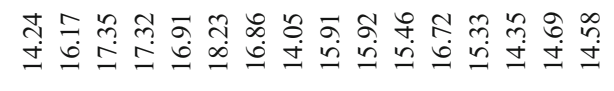 \\
\hline & $\overline{\mathrm{g}}$ & 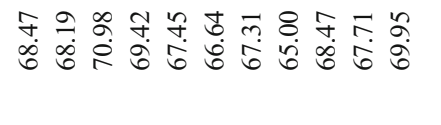 & 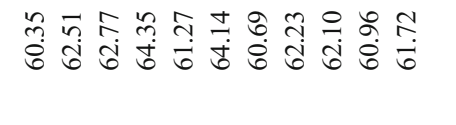 & 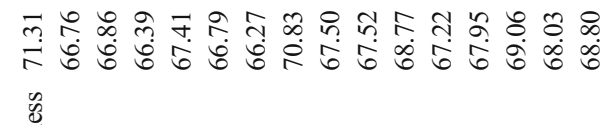 \\
\hline & 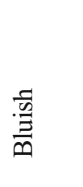 & 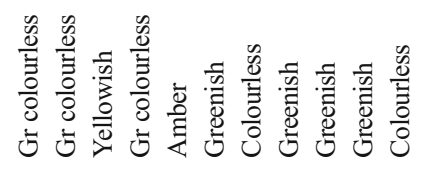 & 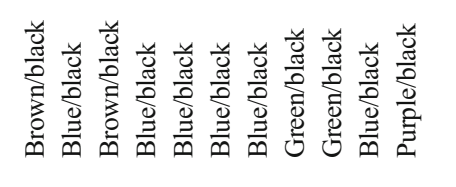 & 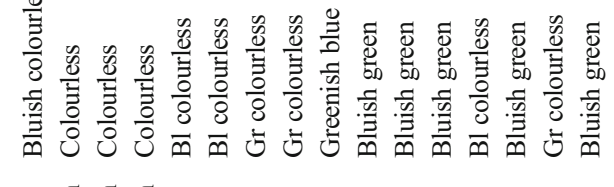 \\
\hline & 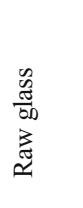 & 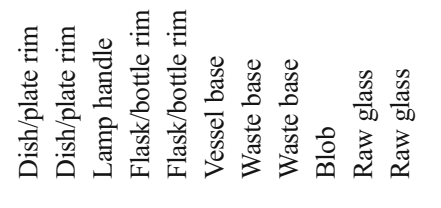 & 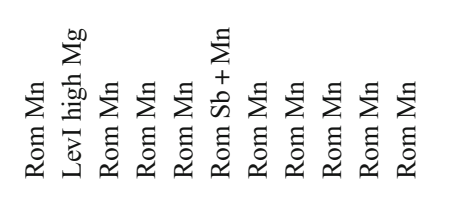 & 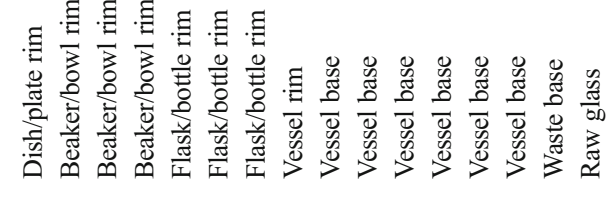 \\
\hline & & & & \\
\hline
\end{tabular}




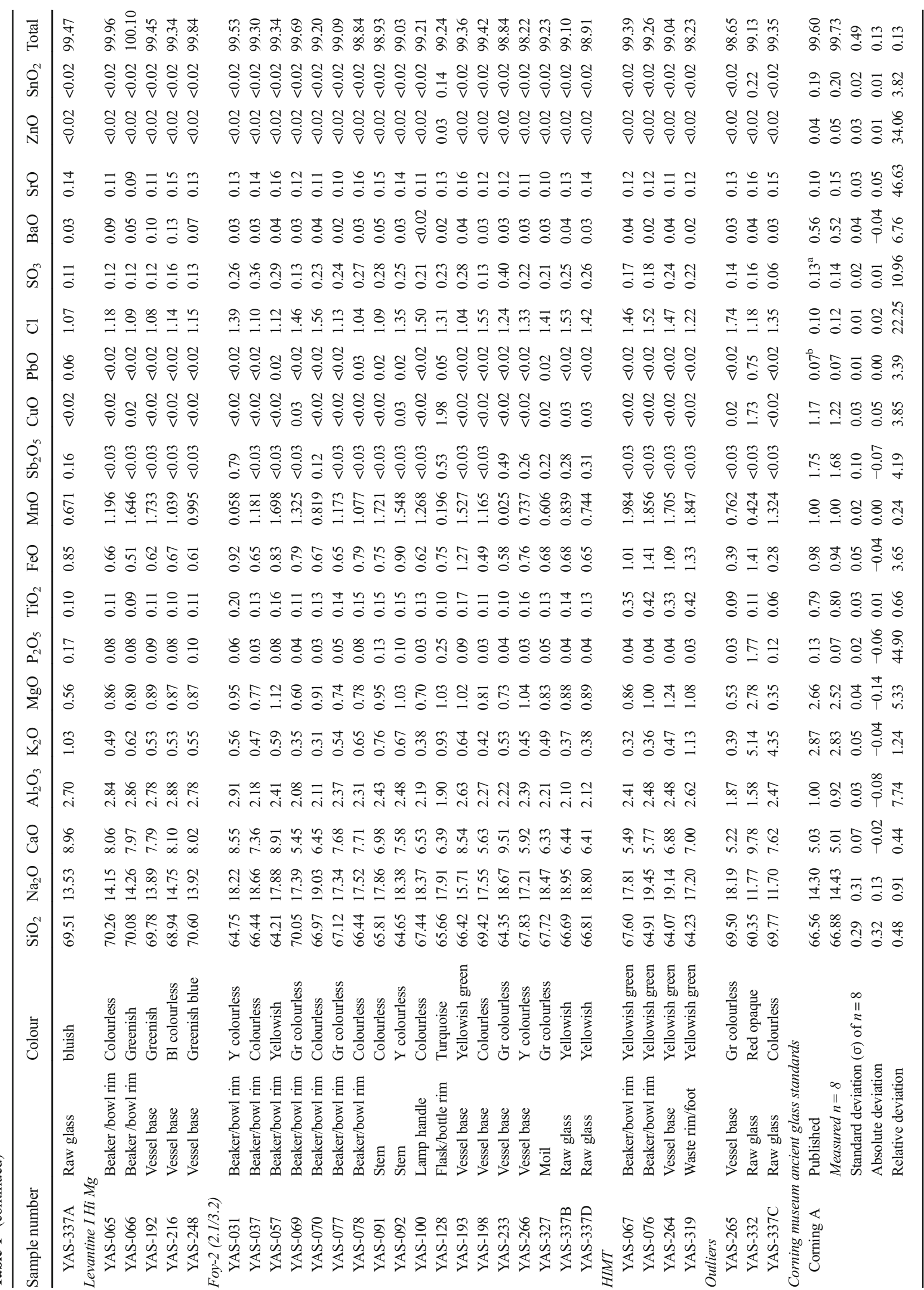




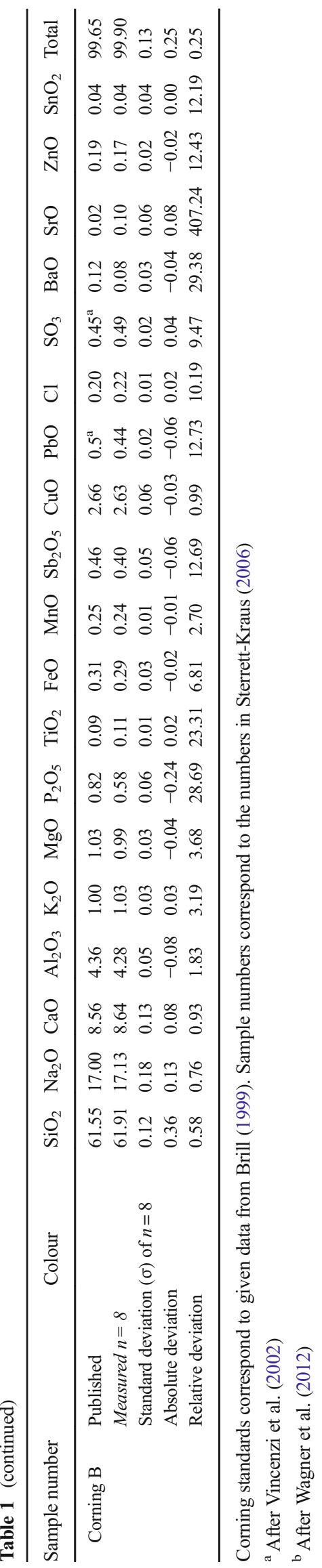

alumina and other oxides as is typical of Roman antimonydecolourised glass (Gliozzo et al. 2015; Jackson 2005; Silvestri et al. 2008).

Rom-Sb glasses show a strong correlation of $\mathrm{MgO}$ and $\mathrm{FeO}$ (Fig. 4a). The spread along the linear trend line is likely to indicate variations in the heavy mineral contents of the glassmaking sand due to sedimentary effects in the depositional environment. The strong correlation, together with weaker correlations with $\mathrm{Al}_{2} \mathrm{O}_{3}$ (Fig. 4b) and $\mathrm{TiO}_{2}$ reflects the more or less constant ratios between the different heavy minerals, such as amphibole, pyroxene and spinel. While a contamination by these elements from the corrosion of ceramic melting pots (e.g. Jackson and Paynter 2015) could explain correlations of this nature, the slope of the regression line (Fig. 4a) indicates that the added material has a weight ratio of $\mathrm{MgO}$ to $\mathrm{FeO}$ of about $2: 1$. Such a ratio would be very unusual in an archaeological ceramic, where $\mathrm{FeO}$ generally dominates $\mathrm{MgO}$. These correlations are more consistent with heavy minerals such as pyroxene and amphibole, which are abundant in the Nile-derived heavy mineral assemblages of the primary glassmaking regions of the eastern Mediterranean (e.g. Freestone et al. 2009b Fig. 1.5).

$\mathrm{MgO}$ and $\mathrm{FeO}$ also correlate with $\mathrm{MnO}$ with a weight ratio of $\mathrm{FeO}$ to $\mathrm{MnO}$ in the order of 10:1 (Fig. 4c). As noted by Freestone et al. (2005), this approximates the ratio of these components in the earth's crust and suggests that this is a natural relationship and reflects the mineral composition of the glassmaking sand rather than manganese additions during glassmaking. The correlation breaks down at $\mathrm{MnO}$ concentrations above $0.025 \%$, suggesting that $250 \mathrm{ppm}$ is effectively the upper limit for naturally occurring (sand-derived) $\mathrm{MnO}$ in this group. Higher levels of $\mathrm{MnO}$ are therefore attributed to the addition of pyrolusite $\left(\mathrm{MnO}_{2}\right)$ as a decolouriser. The Rom$\mathrm{Sb}$ glasses as defined have evidently not been significantly modified by recycling or mixing with a manganese-bearing glass (N.B. Fig. 4 and Table 1 show sample YAS-320C with $0.04 \% \mathrm{MnO}$ as part of the Rom-Sb group for illustrative purposes, although some of the $\mathrm{MnO}$ in that sample represents added material). It is in principle possible that a recycling process was undertaken whereby the Rom-Sb glass was recycled only with $\mathrm{Sb}$-decolourised glass of essentially the same composition and carefully protected from contamination with manganese-containing glass. Indeed, as has been pointed out (e.g. Jackson and Paynter 2015), it is very likely that the glassworkers of the Roman period conserved their colourless glass carefully and tried to prevent it from being adulterated with colour during the recycling process. However, a perfect separation of colourless manganese glass from antimonydecolourised glass during recycling is not easily attainable, because it would not have been possible to distinguish the two types by eye. Therefore, most of the Rom-Sb glass analysed here appears to represent a more or less pristine glass that had not undergone recycling or mixing of any kind. 

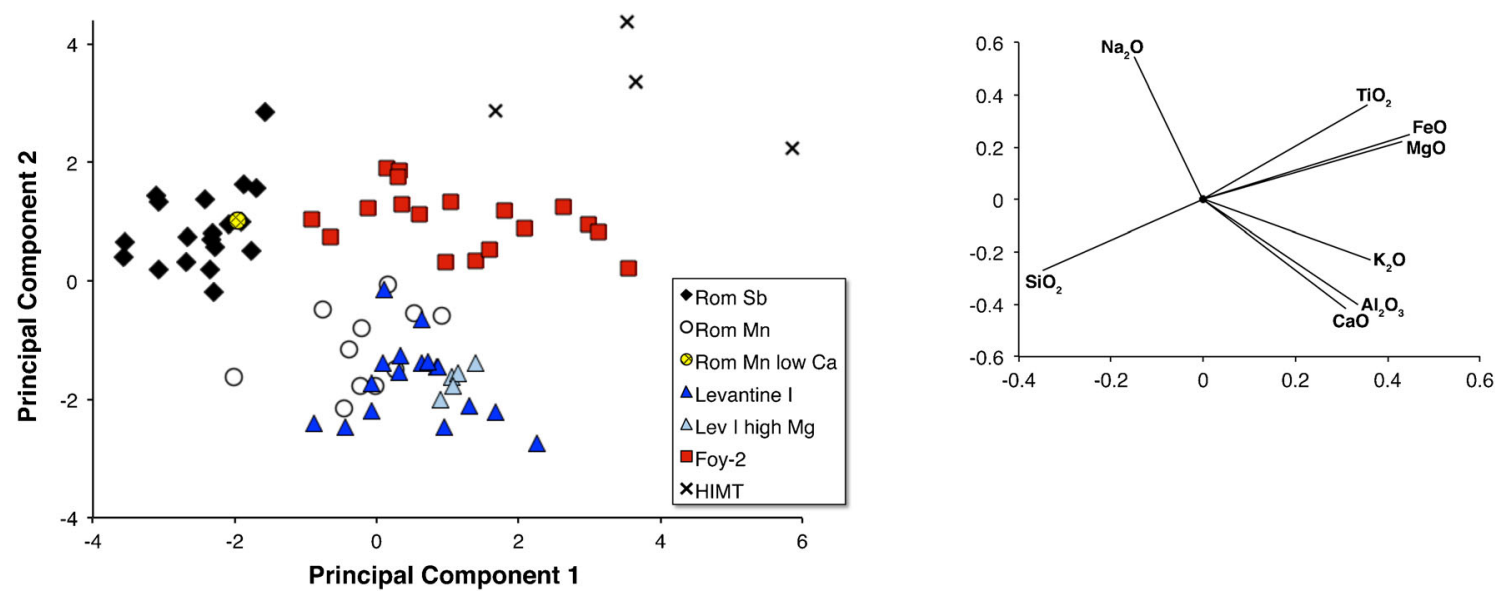

Fig. 3 PCA of eight base glass components. Six primary production groups are clearly separated by the different amounts of flux $\left(\mathrm{Na}_{2} \mathrm{O}\right)$, varying concentrations of $\mathrm{FeO}, \mathrm{TiO}_{2}$ and $\mathrm{MgO}$, reflecting the heavy minerals of the silica source, as well as $\mathrm{CaO}$ and $\mathrm{Al}_{2} \mathrm{O}_{3}$, reflecting the

lighter elements such as feldspar and lime. The length and direction of the vectors (right) are given on an enlarged scale and show the contribution of each variable to the principal components 1 and 2

Not all of the antimony-decolourised glasses are strictly colourless, as some are tinted blue or green when viewed down the break. In these cases, antimony has served to reduce but not fully remove the colour, which depends also on the redox conditions during firing. However, the effectiveness of antimony as a decolourant is illustrated in Table 1, where it is observed that the glasses, which were designated as colourless when selected for analysis, have in general higher antimony contents than those that were recorded as tinted.

\section{Roman manganese-decolourised glasses}

This group comprises mainly glass with manganese above background levels $(\mathrm{MnO}>0.025 \%)$ and $\mathrm{Sb}_{2} \mathrm{O}_{5}$ below the detection limits of our analytical technique (ca. $0.03 \%$ ). Relative to Rom-Sb glass, it has lower soda, higher lime and alumina, along with marginally higher potash, magnesia and iron oxide levels (Fig. 3). The Roman manganesedecolourised group (Rom-Mn) incorporates both the $M n$ and low Mn groups of Jackson and Paynter (2015), which have more or less identical base glass compositions and are likely to

represent the same primary glassmaking sand. It includes a single sample (104) with $\mathrm{MnO}$ below detection limits but which is identical in other respects (Table 1). The low manganese contents of this and one other sample (129) are likely to be reflected in their colour technology, for these are yellowish or amber in colour, probably due to the ferrisulphide chromophore. The formation of this colour required reducing conditions and would have been favoured in a glass which had not been oxidised for the purpose of decolouration by the addition of Mn or Sb (Freestone and Stapleton 2015).

\section{Roman mixed antimony and manganese glass}

This group represents glass that contains both antimony and manganese in concentrations that point to the deliberate addition of these elements at some point during the lifecycle of the material $\left(\mathrm{Sb}_{2} \mathrm{O}_{5}>\right.$ detection limit of ca. $0.03 \%, \mathrm{MnO}$ $>0.025 \%$ ). On the basis of its alumina and lime contents, this group is clearly associated with typical Roman weakly coloured glass that dates mainly to the first to third centuries CE (Gliozzo et al. 2015; Jackson and Paynter 2015; Silvestri

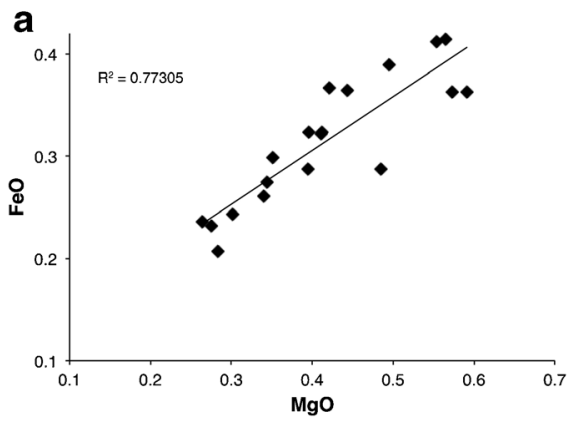

Fig. 4 Chemical characteristics of Roman antimony-decoloured glasses. a Correlation of $\mathrm{FeO}$ and $\mathrm{MgO}$ in Rom-Sb glass, indicating the variations of heavy minerals in the glassmaking sand; $\mathbf{b}$ correlation of $\mathrm{FeO}$ and $\mathrm{Al}_{2} \mathrm{O}_{3} ; \mathbf{c}$ correlation of $\mathrm{MnO}$ and $\mathrm{FeO}$, determining that the maximum
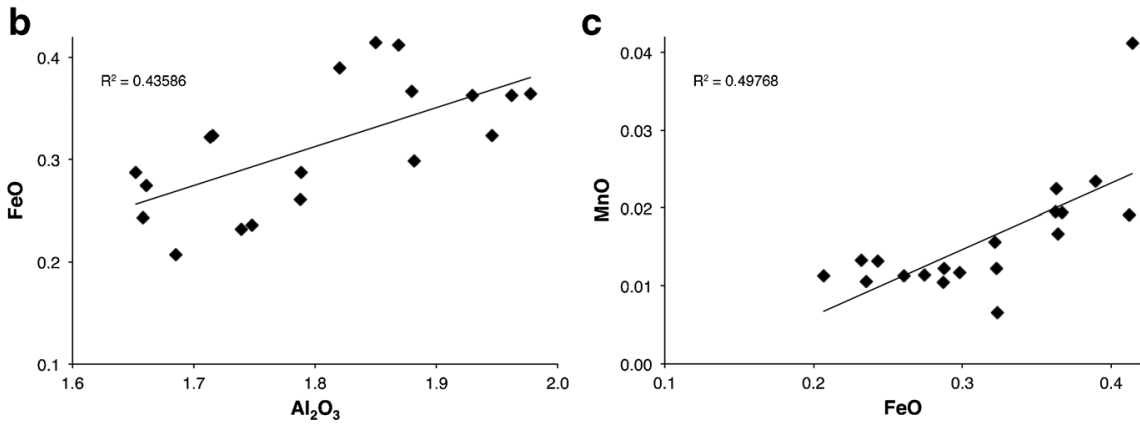

value for naturally occurring $\mathrm{MnO}$ is around $0.025 \%$ or $250 \mathrm{ppm}$. The outlier (sample YAS-320C with $0.04 \% \mathrm{MnO}$ ) appears to include deliberately added manganese 
2008; Silvestri et al. 2008). This mixed glass is situated between Rom-Sb and Rom-Mn glass in terms of its base glass components (Table 1), and the fraction of manganese in the total concentration of decolourants across all three types shows a strong correlation with alumina (Fig. 5). The particular power of this method of presentation of the data (Freestone 2015) is that, in contrast to the simple plotting of manganese and antimony concentrations, it also shows a component of the primary glassmaking sands, thereby providing much stronger evidence that the mixed glasses originate from the recycling and mixing of just two end members, the highalumina Rom-Mn and the low-alumina Rom-Sb types (Jackson 2005; Jackson and Paynter 2015; Silvestri 2008). Furthermore, as will be seen below, departures from the linear mixing relationship can also be very informative.

\section{Levantine I}

Levantine I glass has similar characteristics to Rom-Mn. The term was coined by Freestone et al. (2000) to include a range of late Roman/early Byzantine natron glasses associated with sites in the eastern Mediterranean, and it has since been widely used. When the term was first introduced, the available analytical data on Roman glass were limited and biased towards what have since been defined as the Rom-Sb and Sb-Mn groups, so it was not recognised that there was a gradation and overlap between the Rom-Mn type composition and late Roman or Byzantine Levantine I glass. It is increasingly clear that the situation is much more complex than presented in earlier studies. For example, it is now evident that the fourth-century glass from Jalame in Israel, analysed by Brill (1988) and incorporated by Freestone et al. (2000), into the Levantine I group is compositionally as close, if not closer, to

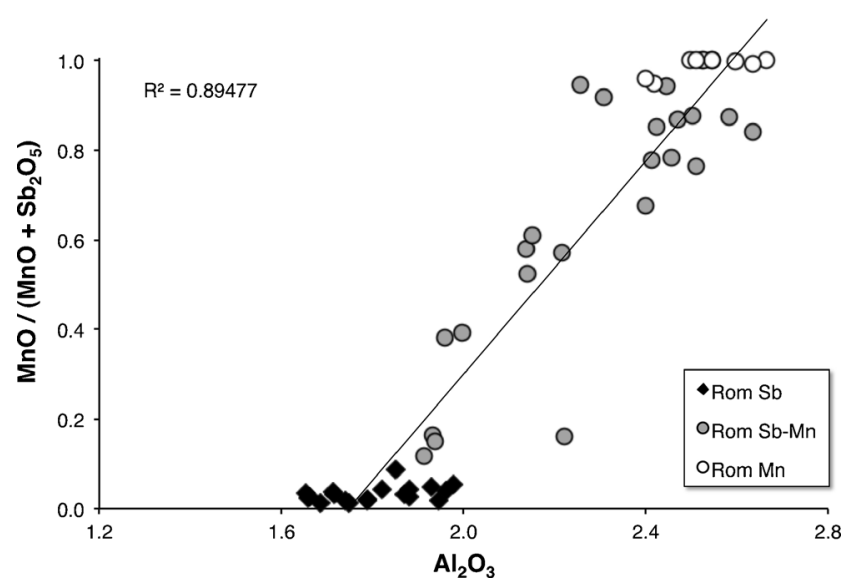

Fig. 5 Correlation of the fraction of manganese in the total concentration of decolourants and alumina in all three Roman glass groups. The strong positive correlation demonstrates the mixing of Rom-Sb and Rom-Mn end members for the production of Sb-Mn glasses. Fe-black glasses (Table 1) are omitted the Rom-Mn glasses of the preceding centuries as to the sixthto seventh-century Levantine I glass production at Apollonia analysed by Tal et al. (2004) and Freestone et al. (2008b). Levantine I has typically higher lime and alumina than Roman glass, often in excess of 8 and $2.8 \%$, respectively. So-called Levantine II glass dates to the seventh to eighth centuries and has higher alumina still (Freestone et al. 2000, 2015). Overall, there appears to be a general shift in the composition of Levantine glasses over time towards compositions richer in alumina (see also Henderson 2013). This probably occurred as a series of steps associated with changes in the sand source, as seen in the shifts in production between Jalame (fourth century), Apollonia (sixth and seventh centuries) and Bet Eli'ezer (eighth century) rather than as a steady increase.

The present paper assumes a chronological dimension and the subdivision of the Levantine glasses based on the discernible increase in alumina with time. Taking the material from the Iulia Felix shipwreck that can be dated to the first half of the third century CE (Silvestri 2008) as representative of Roman glass compositions, the maximum value of $2.69 \%$ alumina was used to provisionally separate the Yasmina assemblage into the Rom- $\mathrm{Mn}\left(\mathrm{Al}_{2} \mathrm{O}_{3}<2.69 \%\right)$ and Levantine I $\left(\mathrm{Al}_{2} \mathrm{O}_{3} \geq 2.69 \%\right)$ groups. Glass with a higher alumina concentration is more likely to date to the fourth century or later and was thus assigned to the Levantine I group. This cut-off is provisional and somewhat arbitrary but may provide an estimation of the relative quantities of first to fourth century as compared to fourth- to sixth-century material. It is acknowledged that a sharp boundary does not exist and that a wider application of the approach would depend crucially on the reproducibility and comparability of the measurement of $\mathrm{Al}_{2} \mathrm{O}_{3}$ between laboratories. However, this division highlights the fact that earlier and later glasses are present among the Yasmina assemblage, given the range of compositions. As will be seen, the threshold chosen appears archaeologically meaningful, for example, with respect to the black bracelets.

\section{Levantine I sub-group—-high MgO}

A small group of samples corresponds to typical Levantine I glass with the exception of elevated $\mathrm{MgO}$ concentrations at around $0.9 \%$. A small amount of similar high $\mathrm{MgO}$ glass was detected among the Levantine I material from a primary furnace at Apollonia (Tal et al. 2004). It is assumed here that this reflects natural variation in the raw material, probably due to a local variation in heavy minerals evidenced also by the higher barium oxide levels (Table 1). As can be observed from the PCA plot (Fig. 3), these Levantine I high $\mathrm{MgO}$ glasses form a tight compositional group and are likely to represent a single consignment (e.g. basket or barrel) of glass from the primary furnace. 


\section{Foy-2}

This group contains mainly samples that correspond to the primary production group série 2.1 of Foy et al. (2003). Like these, the Carthage Foy- 2 glasses have elevated iron, titanium and magnesium concentrations compared to, for example, the Rom-Mn and Levantine I groups (Fig. 3). In this respect, Foy2 is also consistent with série 3.2, yet another primary glass defined by the same authors (Foy et al. 2003). As already suggested by Cholakova et al. (2015), the two glass groups (série 2.1 and série 3.2) are closely related and they differ mainly in terms of their alumina contents. The majority of our Carthage Foy-2 samples lie close to the boundary between the two groups as originally categorised by Foy et al. (2003). Given that the total number of samples is relatively small, we have merged them into a single group and referred to it as Foy2 on account of the compositional features of the primary glass group as first identified and characterised by Foy and colleagues (2003).

Except for the elevated levels of iron, titanium and magnesium oxides, the Foy-2 glasses are similar to the Roman SbMn group with regard to their lime and alumina contents. Soda concentrations are on average just below those of Rom-Sb glasses, but notably higher than those of other Roman and Levantine I groups (Fig. 3). However, they have added manganese rather than antimony. Glass with similar characteristics has previously been linked to the HIMT glass type and referred to as "weak HIMT" (Rosenow and Rehren 2014) or "HIMT 2" (Conte et al. 2014; Foster and Jackson 2009) as they also have elevated iron, magnesium, manganese and titanium oxide concentrations relative to Rom-Sb and Rom-Mn. However, in Foy-2 glass, the correlation between these elements is less pronounced and its high lime and low titanium oxide contents clearly discriminates it from the HIMT group.

The production of Foy- 2 can be assigned to the fifth and sixth centuries CE thanks to more or less well-dated comparative data. Foy et al. (2003), for example, date their série 3.2 to the late fifth and early sixth century and their série 2.1 to the mid-sixth to mid-seventh century. Recent studies have substantiated a fifth-century date for série 3.2 (Cholakova et al. 2015; Gallo et al. 2014; Maltoni et al. 2015), and place série 2.1 generally in the sixth century (HLIMT of Ceglia et al. 2015; Cholakova et al. 2015). Similar characteristics to one or both of these groups can be found in a range of early medieval glass assemblages from southern France (Foy et al. 2003), Anglo-Saxon Britain (Freestone et al. 2008a), Frankish Germany (Wedepohl et al. 1997), Merovingian France (Velde 1990), seventh-century Rome (Mirti et al. 2000), fifth-sixth century Butrint (Conte et al. 2014; Schibille 2011), fifth-sixth century Bulgaria (Cholakova et al. 2015) and sixth century
Cyprus (Ceglia et al. 2015). Taken together, this evidence points to a fifth- to sixth-century date for our composite group Foy-2.

\section{High iron, manganese and titanium glass}

Only four samples correspond to the widespread HIMT glass type (Foy et al. 2003, série 1; Freestone 1994; Freestone et al. 2005). HIMT glass is distinct from the other groups, including Foy-2, by particularly high contents of titanium and manganese as well as significantly elevated levels of iron and magnesium. HIMT glass tends to have relatively low lime and high soda levels compared to Roman manganese or Levantine I glasses and dates typically to the fourth and fifth centuries CE (Foster and Jackson 2009; Foy et al. 2003).

\section{Black glass bangles}

These glasses have been deliberately coloured by the addition of up to $10 \%$ iron oxide (Table 1). Other components that can be associated with the addition of iron in mineral form $\left(\mathrm{TiO}_{2}\right.$, $\mathrm{MnO}, \mathrm{MgO}$ ) are not perturbed by these iron additions. It therefore seems probable that iron was added as scale from heating scrap iron to high temperatures, for which micromorphological evidence has previously been reported (Cholakova and Rehren 2012). Glassworkers were certainly familiar with the colouring properties of iron scale, as it will have formed on the surfaces of blowpipes and other iron tools when manipulating hot glass. The high concentration of iron oxides in this group has led us to exclude them from the multivariate statistical analysis. However, when allowing for dilution by up to $9 \% \mathrm{FeO}$, most bangles correspond to the earlier Rom-Mn group, rather than Levantine I on account of the low alumina levels. Only one sample (292) with greater than $2.69 \% \mathrm{Al}_{2} \mathrm{O}_{3}$ belongs to the Levantine I high $\mathrm{MgO}$ subgroup, while one specimen contains detectable $\mathrm{Sb}$ and can be attributed to the $\mathrm{Sb}-\mathrm{Mn}$ group. The compositional spread of the core Rom-Mn black bangles is quite limited and variances on the oxide contents of this group are about half those on, for example, the colourless and green-blue Rom-Mn glasses. This may suggest that this larger subset of the black bangles are the products of a relatively limited period of activity before Levantine I was being used on a significant scale thereby supporting the chronological division of the glass into Rom$\mathrm{Mn}$ and Levantine I.

\section{Outliers}

Sample 265 is the sole analysed representative of manganesedecoloured Roman glass with low lime, low alumina and high soda. It closely resembles Rom-Sb but contains manganese as a decolouriser rather than antimony. This is a relatively unusual glass type, but has been identified, for example, among 
fourth-century Roman glasses from the British Isles (Foster and Jackson 2010, "colourless 2a"). In the figures, it is indicated as Rom-Mn low Ca.

Two pieces of glass waste have potash levels in excess of $4 \%$, pointing to the addition of a plant ash component in one form or another. Sample 332 is a fairly typical example of a Roman low-copper, low-lead, opaque red glass to which fuel ash was added during the production process as reducing agent. So even though it resembles a plant ash base glass on account of its high potash and magnesia levels, this sample may originally have been a natron-type glass. Sample $337 \mathrm{C}$ has similarly been contaminated by potash in the workshop, as documented in experimental glassmaking studies (Paynter 2008) and in consumer and workshop assemblages (Rehren et al. 2010; Schibille et al. 2012; Tal et al. 2008). These two items are not considered further in the discussion.

\section{Discussion}

\section{Chronology}

The compositional classification of the Carthage glasses allows the dating of the glass working activity on the site to be constrained. Most studies agree that by the end of the fourth century, the use of antimony as a decolourant had more or less ceased, and data on Romano-British glass suggests that this had occurred by around 350 CE (Jackson and Paynter 2015). The presence of Rom-Sb glass in the Yasmina assemblage, including waste items such as lumps, moils and threads, indicates that it was worked at Carthage prior to the middle of the fourth century. Mixed Sb-Mn glass is likely to date to the same period, reflecting recycling activities. Consequently, some glass of the Rom-Mn type must also date to the fourth century or earlier. This firm dating of the use of Mn-decolourised glass to the fourth century or earlier supports our sub-division into earlier Rom-Mn and later Levantine I glass. Even so, an interesting aspect of the Levantine I group is that the glass has also been decolourised with manganese. While manganese was used in fourth-century assemblages such as Jalame (Brill 1988), it is not typical of sixth- to seventh-century Levantine I glass from the primary furnaces in Syria-Palestine (Freestone et al. 2000, 2008a; Tal et al. 2004) nor of consumer assemblages including material dating from the fifth to seventh centuries. These contain up to around $0.1 \% \mathrm{MnO}$ (e.g. Rehren et al. 2010), which in some cases might be indicative of recycling of old manganese decolourised glass but does not suggest contemporary additions. According to Foy et al. (2003), the use of Levantine glass decolourised with manganese in the west dates to the late fourth and early fifth centuries (série 3.1), whereas in the seventh to eighth centuries, it is free of added $\mathrm{MnO}$ (série 3.3). Similarly, high concentrations of $\mathrm{MnO}$ are relatively frequent in fifth-century Levantine I glass from Aquileia (Gallo et al. 2014; group AQ/2a), but only $10 \%$ of Levantine I glass from sites on Cyprus dating from the fifth to seventh centuries have deliberately added manganese (Ceglia et al. 2015). Hence, glass assigned to the Levantine I group in the present study, which invariably contains high concentrations of $\mathrm{MnO}$, probably dates to the late fourth to fifth centuries. From the works cited, such a preponderance of $\mathrm{MnO}$ is not to be expected if the use of these glasses stretched into the sixth and seventh centuries. An important assumption here is that $\mathrm{MnO}$ was added to the glass at the primary production stage, which is becoming increasingly likely (e.g. Nenna 2015). The presence of production waste among the Foy-2 type glasses confirm that glassworking activity on the site continued through the fifth and extended into the sixth century. It is not possible to state with any confidence that glassworking extended beyond this.

\section{Possible workshop group}

In this context, we have paid special attention to a group of vessel bases postulated as the products of a single workshop during the initial post-excavation analysis of the glass forms (Fig. 2). Table 2 shows the samples attributed to this workshop group, their compositional affiliations and possible batch membership. Three compositional groups are present in this sub-assemblage. The majority of glass is of the Rom-Sb or Rom Sb-Mn type. As just discussed, these categories are likely to have been used more or less contemporarily, one representing fresh glass, the other recycled material. They probably date to around or before the middle of the fourth century $\mathrm{CE}$ and are fully consistent with the attribution to a single workshop operating over a relatively limited

Table 2 Suspected workshop group, showing compositional affiliations and possible batches

\begin{tabular}{llll}
\hline Sample Number & Colour & Compositional Group & Batch \\
\hline YAS-210 & Greenish blue & Levantine I & Batch A \\
YAS-213 & Bluish green & Levantine I & Batch A \\
YAS-222 & Bluish green & Levantine I & \\
YAS-208 & Bluish green & Roman Sb-Mn & Batch B \\
YAS-217 & Bluish & Roman Sb-Mn & Batch B \\
YAS-214 & Colourless & Roman Sb & Batch C \\
YAS-228 & Gr colourless & Roman Sb & Batch C \\
YAS-231 & Y colourless & Roman Sb & Batch D \\
YAS-232 & Y colourless & Roman Sb & Batch D \\
YAS-207 & Bluish & Roman Sb-Mn & \\
YAS-229 & Bl colourless & Roman Sb-Mn & \\
YAS-211 & Colourless & Roman Sb & \\
YAS-226 & Colourless & Roman Sb & \\
YAS-230 & Gr colourless & Roman Sb & \\
\hline
\end{tabular}


chronological span. Three samples are assigned to Levantine I. They form a tight compositional group and, considering the increase in alumina over time, their high $\mathrm{Al}_{2} \mathrm{O}_{3}$ contents (3.06-3.07\%) imply that they are significantly later than the other samples. A batch analysis, where samples with all elements within two standard deviations on the mean of the analysis are considered to be identical (Freestone et al. 2009a; Price et al. 2005), reveals pairings that are probably the result of the same production events. These batches are illustrated in the binary plot of $\mathrm{Na}_{2} \mathrm{O}$ versus $\mathrm{SiO}_{2}$ (Fig. 6), where the error bars represent typical values of the standard deviation on the mean of the analytical points (ca. $1 \%$ relative for $\mathrm{Na}_{2} \mathrm{O} ; 0.3 \%$ for $\mathrm{SiO}_{2}$ ). The close compositional relationships between vessels of the workshop group confirm the initial archaeological inference that these vessels are closely related and indeed reflect the output of a single workshop, with the exception of the Levantine I samples which appear to be a similar form made somewhat later in time.

The converse to the identification of batches is that the typological variety of these vessels may be linked to secondary workshop practices. As is clear from Fig. 2, typological variation exists even among vessels that were possibly made from the same batch. For example, in the case of the Rom-Sb vessels attributed to the same production event (YAS-214 and 228; YAS-231 and 232), both diameter (coefficient of variation $(\mathrm{CV})=0.28)$ and base thickness $(\mathrm{CV}=0.33)$ vary considerably, though there are obvious similarities in form: a thick, (nearly) flat base with flaring walls, probably deriving from a bulbous bowl or jug. The large CV of these vessel bases suggests that they are not sufficiently similar to have come from the hand of a single expert glassworker (Longacre 1999; Sterrett-Krause 2009). Instead, multiple glassworkers might have been using the same batch of melted glass to produce vessels of the same type but with variations due to differences in skill and experience. It is easy to imagine that several glassworkers were active in the same Roman workshop at any

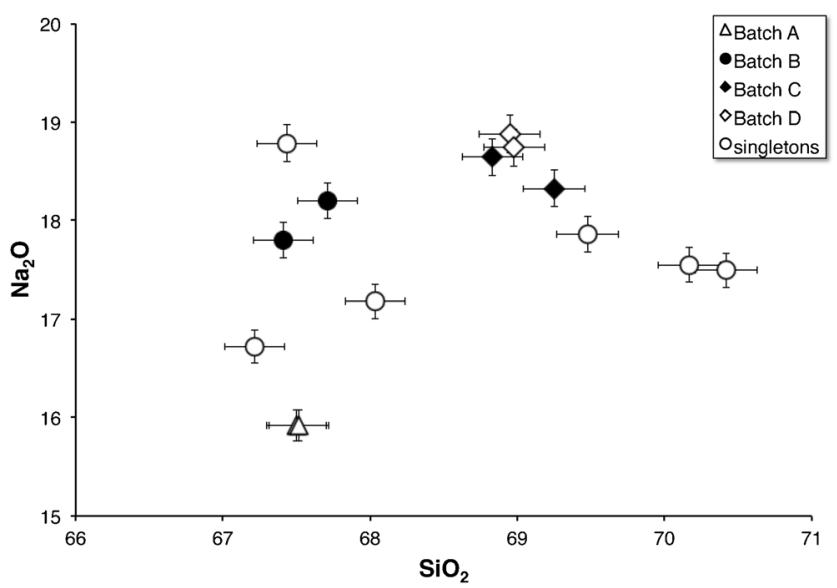

Fig. 6 Workshop clusters. Soda and silica contents for the workshop group samples with error bars $\left(1 \%\right.$ relative for $\mathrm{Na}_{2} \mathrm{O}$ and $0.3 \%$ for $\mathrm{SiO}_{2}$ ), showing the clustering of possible batches given time. In contrast, there is slightly more standardization among the vessel bases of the Levantine I group (base diameter $\mathrm{CV}=0.10$ ), which could in turn indicate a change in the organization of glass workshop in the late fourth to sixth century CE. This, however, can remain but a hypothesis due to the small sample size that potentially masks the true degree of variability among the assemblage.

\section{Recycling}

It has already been demonstrated that Rom Sb-Mn was produced through the recycling and mixing of essentially two primary glass types, Rom-Sb and Rom-Mn. Here, we further explore changes due to recycling, based on the linear mixing behaviour of these end members (Figs. 5 and 7). Some of these changes have been demonstrated in Roman glass from Britain by Jackson and Paynter (2015). However, it is important to identify the effects and extent of recycling over a range of assemblages because variations are likely to reflect local connectivity and prevailing economic conditions, as well as technologies and the configuration of the glassworking furnaces used, which will have varied from place to place. We base our analysis on the relationship between the $\mathrm{MnO}$ / $\left(\mathrm{MnO}+\mathrm{Sb}_{2} \mathrm{O}_{5}\right)$ ratio and base glass components (Figs. 5 and 7) as introduced by Freestone (2015). This approach is more powerful than, for example, binary plots of antimony versus manganese oxides alone because, where analytical data are sufficiently precise as in the present case and in some other studies using EPMA analysis (e.g. Silvestri et al. 2008), the linear relationship demonstrates the involvement of only two primary glass end members. The variations in antimony and manganese contents of the end members do not allow this simple confirmation when using $\mathrm{Mn}$ and $\mathrm{Sb}$ oxides as coordinates. Furthermore, departures from linearity using the ratio plot reflect additional contaminants of the glass, whether through a third primary glass or, as argued here, through contamination during re-melting and recycling.

The linear relationship illustrated in Fig. 5 indicates that any contamination of the glass by alumina from ceramic melting pots or tank walls did not have a substantial effect on its composition, in spite of apparent re-melting. Although it has been suggested that contamination during melting from the enclosing ceramic may alter the composition of Roman glass (Jackson and Paynter 2015), we see limited evidence of this in the Yasmina assemblage. Just a single point in the lower part of Fig. 5 lies sufficiently to the right of the mixing line to present strong evidence for alumina contamination. This scant evidence for alumina contamination is likely to be due to a number of factors. First, the formation of a highly viscous boundary layer of contaminated glass between the wall of the ceramic and the bulk of the glass is likely to have inhibited any such reaction so that it was less effective than might intuitively be considered to have been the case. In addition, while 

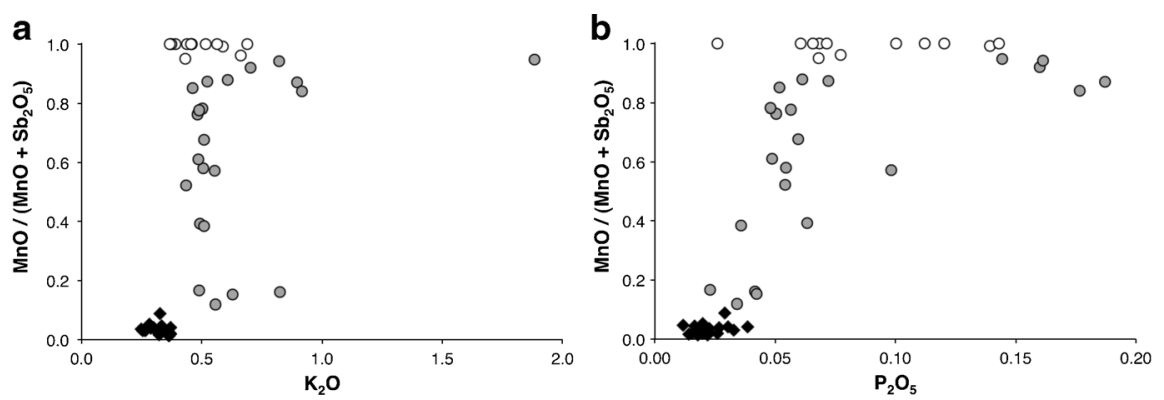

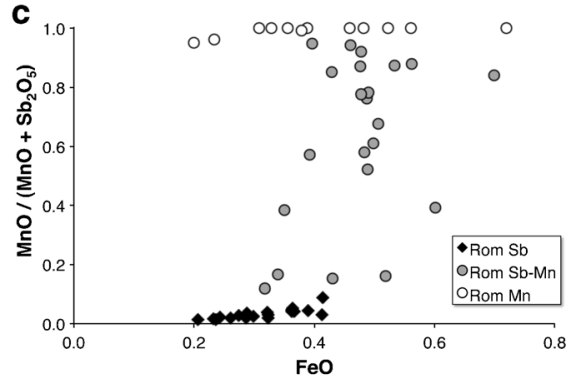

Fig. 7 Contaminations of Roman glasses associated with recycling. a Fraction of $\mathrm{Mn}$ in the total concentration of decolourants and $\mathrm{K}_{2} \mathrm{O}$ for Rom-Sb, Rom Sb-Mn and Rom-Mn, revealing an excess of $\mathrm{K}_{2} \mathrm{O}$ in mixed Sb-Mn glasses, due to contamination from fuel ash and vapour; b $\mathrm{Mn}$ fraction and $\mathrm{P}_{2} \mathrm{O}_{5}$ concentrations for Rom-Sb, Rom Sb-Mn and
Rom-Mn, showing a large variability and elevated levels of $\mathrm{P}_{2} \mathrm{O}_{5}$ in some of the mixed Rom Sb-Mn glasses; $\mathbf{c}$ Mn fraction and FeO levels for Rom$\mathrm{Sb}$, Rom Sb-Mn and Rom-Mn, indicating $\mathrm{FeO}$ contaminations in the recycled Rom Sb-Mn glasses, possibly due to the use of iron tools during recycling a limited number of Roman glass melting pots are known, there is also significant evidence that tanks rather than crucibles were used in many Roman and Byzantine glass workshops (e.g. Gorin-Rosen 2000; Foy and Nenna 2001; Shepherd 2015). The greater volume to surface ratio of tanks makes significant contamination of the glass melt from the container wall less likely. In glass production debris at Roman York, on the other hand, there is evidence of smallscale glass melting in crucibles, rather than tanks (Jackson et al. 2003), and crucible contamination has indeed been identified (Jackson and Paynter 2015). Finally, the effect of ceramic contamination on the composition of the base glass will be constrained by the relative proportions of the components in the glass and in the ceramic. Simple arithmetic considerations indicate that the effects of contamination from the dissolution of the wall of a container with $17 \% \mathrm{Al}_{2} \mathrm{O}_{3}$ and $7 \% \mathrm{FeO}$ (the composition of a typical alluvial clay) on a glass which contains $2.5 \% \mathrm{Al}_{2} \mathrm{O}_{3}$ and $0.4 \% \mathrm{FeO}$ will be far more apparent for iron oxide than for alumina as the increase in iron oxide as a proportion of the original concentration in the glass will be greater.

Recycling practices are further illustrated when comparing the contents of $\mathrm{K}_{2} \mathrm{O}, \mathrm{P}_{2} \mathrm{O}_{5}$ and $\mathrm{FeO}$ for the three Roman groups, plotted against $\mathrm{MnO} /\left(\mathrm{MnO}+\mathrm{Sb}_{2} \mathrm{O}_{5}\right)$ (Fig. $\left.7 \mathrm{a}-\mathrm{c}\right)$. In each case, the mixed Sb-Mn glasses do not lie directly between the median compositions of the two end members. In contrast to the behaviour shown by alumina (Fig. 5), the distributions of $\mathrm{K}_{2} \mathrm{O}$ and $\mathrm{FeO}$ are displaced towards the right of the graphs, showing higher values of these oxides or, in case of $\mathrm{P}_{2} \mathrm{O}_{5}$ larger variability, than might be expected from simple mixing behaviour. This is symptomatic of contaminations that occur when a glass is re-melted (e.g. Paynter 2008; Tal et al. 2008; Rehren et al. 2010; Jackson and Paynter 2015). Specifically, contamination from vapour and ash in the furnace atmosphere increases $\mathrm{P}_{2} \mathrm{O}_{5}$ and $\mathrm{K}_{2} \mathrm{O}$, while iron is augmented by contamination from the container wall (see above) and scale incorporated from the tips of the blowpipe and pontil (incorporation of black glass would also cause an iron contamination). These signs of re-melting are more evident in the mixed Sb-Mn glasses than in the Rom-Sb and Rom-Mn end members. Rom-Sb glass in particular shows little evidence of re-melting in the form of elevated ash-, ceramic-, or toolrelated components. As noted elsewhere, it appears that elevated $\mathrm{K}_{2} \mathrm{O}$ and $\mathrm{P}_{2} \mathrm{O}_{5}$ can be good indicators of recycling, as opposed to the simple re-melting of primary glass for the first time (Jackson and Paynter 2015; Freestone 2015; Rehren and Brüggler 2015).

Increased potassium and phosphorus contents in the other glass groups similarly testify to recycling (Fig. 8). The Levantine I and Foy-2 groups have $\mathrm{K}_{2} \mathrm{O}$ and $\mathrm{P}_{2} \mathrm{O}_{5}$ distributions comparable to those in Rom Sb-Mn glass. Furthermore, some of the Foy-2 glasses have significant $\mathrm{Sb}_{2} \mathrm{O}_{5}$ concentrations, suggesting that recycling of old Roman glass continued into the fifth century and beyond. Overall, these results show that recycling was standard practice throughout the period of glass working activities at Carthage. This is to be expected in a large metropolis with well-developed infrastructures to support a large-scale recycling economy. It is even conceivable

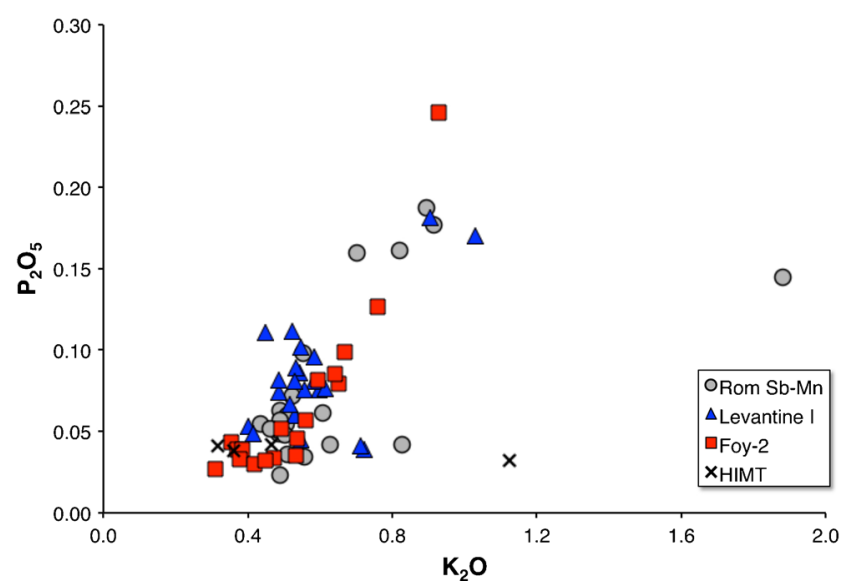

Fig. $8 \mathrm{P}_{2} \mathrm{O}_{5}$ and $\mathrm{K}_{2} \mathrm{O}$ contaminations. Elevated concentrations of $\mathrm{P}_{2} \mathrm{O}_{5}$ and $\mathrm{K}_{2} \mathrm{O}$ in some of the Rom Sb-Mn, Levantine I, Foy-2 and HIMT glasses are indicative of contaminations through fuel ash and vapour. This provides additional evidence that many of these glasses have undergone recycling processes 
that much of the glass from the Yasmina Necropolis landfill layer might have previously been collected as cullet for recycling.

\section{Primary glass sources}

Given the modifications in the concentrations of many elements during recycling processes, the number of major and minor element components that are diagnostic of provenance are relatively limited. As discussed above, iron oxide, potash and phosphate contents are subject to modification during recycling. Sodium oxide is a variable that depends above all upon the practice of the glassmaker and does not reflect the glassmaking sand. Lime has frequently been used to distinguish glass groups, but it is likewise rather variable within a single group and may be affected by contaminations from fuel ash. Lime together with alumina has been widely used as a first step in separating primary glass production groups, which can indeed be informative (Arletti et al. 2010, Freestone et al. 2000; Freestone et al. 2002b; Gallo et al. 2014, Schibille and Freestone 2013). However, HIMT and Foy-2, for example, are not easily distinguished in these graphs from other glass groups.

Instead, a binary plot of ratios of $\mathrm{TiO}_{2} / \mathrm{Al}_{2} \mathrm{O}_{3}$ versus $\mathrm{Al}_{2} \mathrm{O}_{3} /$ $\mathrm{SiO}_{2}$ proves to be extremely powerful in identifying production groups (Fig. 9), because it relates the chemical composition of the glass to the mineralogy of the glassmaking sands. Within this system, $\mathrm{SiO}_{2}$ represents the quartz content, $\mathrm{Al}_{2} \mathrm{O}_{3}$, the feldspar and $\mathrm{TiO}_{2}$, the heavy minerals in the silica source. This representation of the mineralogical characteristics shows a general disposition of groups similar to that in the principal component analysis (Fig. 3). The correspondence of the multivariate statistical and geochemically based analyses provides strong evidence that our groupings are robust. HIMT glass is clearly singled out, emphasising its high titanium content

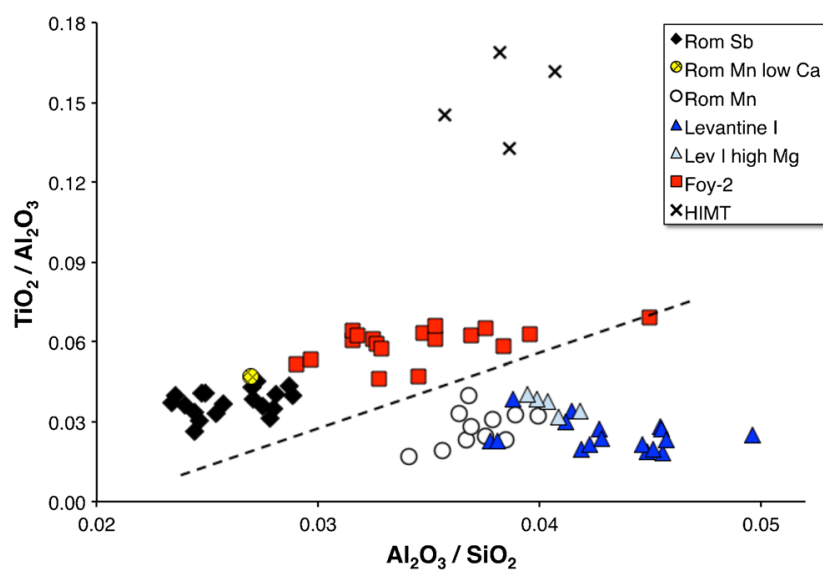

Fig. 9 Primary production groups based on the mineralogy of the glassmaking sand. $\mathrm{TiO}_{2} / \mathrm{Al}_{2} \mathrm{O}_{3}$ and $\mathrm{Al}_{2} \mathrm{O}_{3} / \mathrm{SiO}_{2}$ ratios illustrate key compositional subdivisions into six primary production groups. The dashed line indicates the proposed division between Levantine and Egyptian primary production groups relative to all other groups (Fig. 9). The high ratio of $\mathrm{Al}_{2} \mathrm{O}_{3}$ to $\mathrm{SiO}_{2}$ of the main Levantine groups that include Rom-Mn and Levantine I, reflects the presence of feldspar in the sands of this region. In contrast, antimony-decolourised Roman glass has a substantially lower $\mathrm{Al}_{2} \mathrm{O}_{3} / \mathrm{SiO}_{2}$ ratio. It is significant that although this Roman colourless glass is commonly believed to have been made from a relatively clean sand source, its average $\mathrm{TiO}_{2} / \mathrm{Al}_{2} \mathrm{O}_{3}$ ratio is slightly higher than that of the Levantine glasses, which suggests a different provenance. Finally, Foy- 2 occupies the centre of the graph, above the Rom-Sb, Rom-Mn and Levantine I groups, pointing to yet another silica source (Fig. 9).

As noted by Picon and Vichy (2003), high $\mathrm{TiO}_{2}$ is especially characteristic of Egyptian glassmaking sands. On account of its exceptionally high absolute values of $\mathrm{TiO}_{2}$, HIMT glass is therefore generally attributed to an Egyptian origin (Foy et al. 2003; Freestone et al. 2005; Nenna 2014). The elevated values for $\mathrm{TiO}_{2} / \mathrm{Al}_{2} \mathrm{O}_{3}$ of Foy-2 relative to the Levantine glasses (Fig. 9) strongly suggest that its primary production too was located in Egypt. It is important to note that this seems to apply also to série 3.2 of Foy et al. (2003), which is in contrast to the authors' original attribution of this type of glass to a Levantine source. Nonetheless, Foy-2 (both séries 2.1 and 3.2) is clearly distinct from HIMT glass in that it has considerably lower $\mathrm{TiO}_{2}$ and shows strontium isotope ratios different from those of HIMT glass, confirming the use of sands from a different location (Ceglia et al. 2015, Cholakova et al. 2015, Freestone et al. 2008a; Gallo et al. 2015). One of the most significant observations is that the composition of Rom-Sb lies at one end of the Foy-2 distribution (Fig. 9). This along with the slightly higher mean $\mathrm{TiO}_{2} /$ $\mathrm{Al}_{2} \mathrm{O}_{3}$ ratio compared to glasses from the Levant would seem to locate the primary production of Rom-Sb glasses likewise in Egypt. An Egyptian provenance for Roman antimonydecoloured glasses has been tentatively proposed by Foy et al. (2003, group 4), while Whitehouse pointed out that the Price Edict of Diocletian suggests that Roman colourless glass was made in Alexandria (Whitehouse 2004; but see Barag 2005, for an alternative view). The compositional evidence presented here, together with data from Bubastis in Egypt where Rom-Sb was the predominant glass type (Rosenow and Rehren 2014), supports an Egyptian origin for Roman glasses decoloured using antimony. The high soda content of Rom-Sb (Fig. 3) may further indicate that natron was more readily available to its producers than to the glassmakers of the various Levantine groups, given its closer proximity to the naturally occurring natron sources in Egypt. This differential pattern of soda concentrations can be observed throughout the later first millennium $\mathrm{CE}$ when comparing Egyptian and Levantine productions (Freestone et al. 2015). Based on these geochemical observations, we thus propose a subdivision between primary glasses from Egypt and the Levant along the dashed line in Fig. 9, with Rom-Sb, HIMT and Foy-2 being 
Egyptian and Rom-Mn and Levantine I originating from the Levantine coast.

Finally, a single example of manganese-decoloured glass with a low-lime, low-alumina matrix analysed here falls within the Rom-Sb glass group (Fig. 9). This type of glass corresponds to colourless $2 a$ of Foster and Jackson (2010) and, given its chemical characteristics and close resemblance to the Rom-Sb type, this exceptional sample seems more likely to derive from the same primary production centre as Rom-Sb. One may speculate that the manufacturers of this type of glass turned to the use of manganese rather than antimony when supplies of the latter became problematic, particularly in the fourth century. It is possible that this led ultimately to the decline of this primary production, due to manganese being less effective as a decolouriser, so that the new glass was not as desirable as high status Sbdecoloured glass.

\section{Conclusion}

The overall composition of the glass assemblage from the Yasmina Necropolis is broadly consistent with the dating of the landfill deposit to the third to seventh centuries CE. The fact that glass waste and raw glass chunks were found among all the chronologically distinct glass groups bears witness to on-going secondary glassworking activities at Carthage throughout the Roman and late antique periods. The chemical characteristics of the glass finds also reflect a geographical dimension that indicates the supply of raw glasses to Carthaginian secondary glass workshops from different primary production sites in Egypt and on the Levantine coast. Three of the identified primary glass production groups were evidently produced from Levantine silica sources (Rom-Mn, Levantine I, Levantine I high Mg), while the other three most probably originated from Egypt (Rom-Sb, HIMT, Foy-2). Multivariate statistical evaluation of the data in combination with binary scatter plots of mineralogically significant ratios enabled the geochemical isolation of Rom-Sb glass and the Carthage Foy-2 type (including séries 2.1 and 3.2), and their re-attribution to an Egyptian origin (Foy et al. 2003; Gallo et al. 2015). These newly developed approaches to the interpretation of the analytical data demonstrate how a detailed data analysis can extract insights from what might be considered a relatively unpromising assemblage, where the chronology is not precisely constrained.

If we accept the geographical categorisation of the different primary glass groups, then there is good evidence that glass from Egypt and the Levant were simultaneously imported and processed for most of the period. Until the early fourth century, both Egyptian Rom-Sb and Levantine Rom-Mn glasses were worked at Carthage. Egyptian HIMT, albeit limited in number, and two Levantine I groups were identified amongst the later fourth- and early fifth-century glasses. To judge from the elevated manganese concentrations of virtually all the glasses attributed to the Levantine I type, the influx of Levantine glass appears to cease after the early fifth century. Thereafter, during the fifth and sixth centuries, the Egyptian Foy-2 group predominates, which indicates a shift in the supply of glass and by extension in the maritime trade between Carthage and the primary production centres further east. From the later part of the fifth century, Carthage thus appears to have cultivated tighter trade links with neighbouring Egypt than with Syro-Palestine as regards the import of raw glass.

It would be tempting to relate this shift to the changing geopolitical landscape of the late antique Mediterranean. The secondary glass industry at Carthage evidently survived the Vandal conquest in $439 \mathrm{CE}$, yet the supply of raw glass changed in favour of Egyptian producers. Interestingly, there is no evidence of a general cessation of traffic between Vandal Carthage and the Byzantine held territories in Egypt and the Levant, despite the fact that the relationship between the Byzantine imperial court and the Vandals was tense and seems to have eased only after the endless peace was established in about 474 CE (Procopius 1916, III.8.26; Sarris 2011, p. 89). The ceramic record of the fifth century, for instance, demonstrates an increase in imports of eastern origins, and Carthaginian merchant ships continued to trade widely after the Vandals took control (e.g. Merrills and Miles 2010, pp. 141-176). So, there is no obvious correlation between the new political situation in Vandal conquered Africa, its economic connectivity and the changing supply of raw glass to Carthage. The end of Rome's hegemony in the Mediterranean presumably meant greater economic freedom and choice, but its implications for the distribution patterns and trade of glass are far from clear. Further research is required to shed light on how the social and political developments and fiscal reforms of the post-Roman world affected the ebb and flow of the Mediterranean glass economy.

Acknowledgments For their help in the laboratory, we would like to thank Mr Kevin Reeves and Dr Harriet White. For permission to sample the Yasmina Necropolis glass, we are grateful to Dr Naomi Norman.

This project has received funding from the European Research Council (ERC) under the European Union's Horizon 2020 research and innovation programme (grant agreement No. 647315 to NS). The funding organisation had no influence in the study design, data collection and analysis, decision to publish, or preparation of the manuscript.

Open Access This article is distributed under the terms of the Creative Commons Attribution 4.0 International License (http:// creativecommons.org/licenses/by/4.0/), which permits unrestricted use, distribution, and reproduction in any medium, provided you give appropriate credit to the original author(s) and the source, provide a link to the Creative Commons license, and indicate if changes were made. 


\section{References}

Annabi MK (1992) Deux nécropoles au sud de la ville. In: Ennabli A (ed) Pour sauver Carthage: exploration et conservation de la cité punique, romaine et byzantine. UNESCO, Paris, pp 183-190

Arletti R, Vezzalini G, Benati S, Mazzeo Saracino L, Gamberini A (2010) Roman window glass: a comparison of findings from three different Italian sites. Archaeometry 52:252-271

Barag D (2005) Alexandrian and Judaean glass in the price edict of Diocletian. Journal of Glass Studies 47:184-186

Brems D, Ganio M, Latruwe K, Balcaen L, Carremans M, Gimeno D, Silvestri A, Vanhaecke F, Muchez P, Degryse P (2013) Isotopes on the beach, part 2: neodymium isotopic analysis for the provenancing of Roman glass-making. Archaeometry 55:449-464

Brill RH (1988) Scientific investigations of the Jalame glass and related finds. In: Weinberg GD (ed) Excavations at Jalame: site of a glass factory in late Roman Palestine. University of Missouri, Columbia, pp 257-291

Brill RH (1999) Chemical analyses of early glasses. The Corning Museum of Glass, Corning

Ceglia A, Cosyns P, Nys K, Terryn H, Thienpont H, Meulebroeck W (2015) Late antique glass distribution and consumption in Cyprus: a chemical study. Journal of Archaeological Science 61:213-222

Cholakova A, Rehren T (2012) Producing black glass during the Roman period-notes on a crucible fragment from Serdica, Bulgaria. Proceedings of the 39th International Symposium for Archaeometry, vol 28. Centre for Archaeological Sciences, KU Leuven, Leuven, pp 261-267

Cholakova A, Rehren T, Freestone IC (2015) Compositional identification of $6^{\text {th }} \mathrm{c}$. AD glass from the Lower Danube. Journal of Archaeological Science Reports. doi:10.1016/j.jasrep.2015.08.009

Conte S, Chinni T, Arletti R, Vandini M (2014) Butrint (Albania) between eastern and western Mediterranean glass production: EMPA and LA-ICP-MS of late antique and early medieval finds. Journal of Archaeological Science 49:6-20

Foster HE, Jackson CM (2009) The composition of 'naturally coloured' late Roman vessel glass from Britain and the implications for models of glass production and supply. Journal of Archaeological Science 36:189-204

Foster HE, Jackson CM (2010) The composition of late RomanoBritish colourless vessel glass: glass production and consumption. Journal of Archaeological Science 37:3068-3080

Foy D, Nenna M-D (2001) Tout feu, tout sable: Mille ans de verre antique dans le midi de la France. Museé d'Histoire de Marseille, Édisud, Aix-en-Provence

Foy D, Picon M, Vichy M, Thirion-Merle V (2003) Caractérisation des verres de la fin de l'Antiquité en Méditerranée occidentale: l'émergence de nouveaux courants commerciaux. In: Foy D, Nenna M-D (eds) Échanges et commerce du verre dans le monde antique : actes du colloque de l'Association française pour l'archéologie du verre, Aix-en-Provence et Marseille, 7-9 juin 2001. Éditions Monique Mergoil, Montagnac, pp 41-85

Freestone IC (1994) Appendix: chemical analysis of 'raw' glass fragments. In: Hurst HR (ed) Excavations at Carthage, vol II, 1. The circular harbour, north side. The site and finds other than pottery. British Academy Monographs in Archaeology 4. Oxford University Press, Oxford, p 290

Freestone IC (2005) The provenance of ancient glass through compositional analysis. MRS Proceedings 852:195-208

Freestone IC (2015) The recycling and reuse of Roman glass: analytical approaches. J Glass Stud 57:29-40

Freestone IC, Stapleton CP (2015) Composition, technology and production of coloured glasses from Roman mosaic vessels. In: Jackson C,
Freestone I, Bayley J (eds) Glass of the Roman World. Oxbow Books, Oxford, pp 61-76

Freestone IC, Gorin-Rosen Y, Hughes MJ (2000) Primary glass from Israel and the production of glass in late antiquity and the Early Islamic period. In: Nenna M-D (ed) La route du verre. Ateliers primaires et secondaires du second millénaire av. J.C. au Moyen Âge. Maison de l'Orient Méditerranéen-Jean Pouilloux, Lyon, pp 65-83

Freestone IC, Greenwood R, Gorin-Rosen Y (2002a) Byzantine and early Islamic glassmaking in the eastern Mediterranean: production and distribution of primary glass. In: Kordas $\mathrm{G}$ (ed) Hyalos= vitrum= glass: history, technology and conservation of glass and vitreous materials in the Hellenic world. Panepistemiakes Ekdoseis Phessadias, Athens, pp 167-174

Freestone IC, Ponting M, Hughes MJ (2002b) The origins of Byzantine glass from Maroni Petrera, Cyprus. Archaeometry 44, 257-272

Freestone IC, Wolf S, Thirlwall M (2005) The production of HIMT glass: elemental and isotopic evidence. Annales du 16e Congrès de l'Association Internationale pour l'Histoire du Verre, pp 153-157

Freestone IC, Hughes MJ, Stapleton CP (2008a) The composition and production of Anglo-Saxon glass. In: Evison VI (ed) Catalogue of Anglo-Saxon glass in the British Museum. British Museum, London, pp 29-46

Freestone IC, Jackson-Tal RE, Tal O (2008b) Raw glass and the production of glass vessels at late Byzantine Apollonia-Arsuf, Israel. J Glass Stud 50:67-80

Freestone IC, Price J, Cartwright C (2009a) The batch: its recognition and significance. Annales du 17e Congrès de l'Association Internationale pour l'Histoire du Verre, pp 130-135

Freestone IC, Wolf S, Thirlwall M (2009b) Isotopic composition of glass from the Levant and south-eastern Mediterranean Region. In: Degryse P, Henderson J, Hodgins G (eds) Isotopes in vitreous materials. Leuven University Press, Leuven, pp 31-52

Freestone IC, Jackson-Tal RE, Taxel I, Tal O (2015) Glass production at an early Islamic workshop in Tel Aviv. Journal of Archaeological Science 62:45-54

Fulford MG (1980) Carthage: overseas trade and the political economy, c. AD 400-700. Reading Medieval Studies 6:68-80

Fünfschilling S (1999) Gläser aus den Grabungen des Deutschen Archäologischen Instituts in Karthago. Die Grabungen 'Quartier Magon' und Rue Ibn Chabâat sowie kleinere Sondagen. In: Rakob F (ed) Die deutschen Ausgrabungen in Karthago (Karthago III). Philipp von Zabern, Mainz, pp 435-529

Gallo F, Marcante A, Silvestri A, Molin G (2014) The glass of the "Casa delle Bestie Ferite": a first systematic archaeometric study on Late Roman vessels from Aquileia. Journal of Archaeological Science 41:7-20

Gallo F, Silvestri A, Degryse P, Ganio M, Longinelli A, Molin G (2015) Roman and late-Roman glass from north-eastern Italy: the isotopic perspective to provenance its raw materials. Journal of Archaeological Science 62:55-65

Ganio M, Boyen S, Fenn T, Scott R, Vanhoutte S, Gimeno D, Degryse P (2012) Roman glass across the Empire: an elemental and isotopic characterization. Journal of Analytical Atomic Spectrometry 27: 743-753

Gliozzo E, Lepri B, Saguì L, Turbanti Memmi I (2015) Colourless glass from the Palatine and Esquiline hills in Rome (Italy). New data on antimony- and manganese-decoloured glass in the Roman period. Archaeol Anthropol Sci. doi:10.1007/s12520-015-0264-1

Gliozzo E, Sontagostino Barbone A, D’Acapito F (2013) Waste glass, vessels and window panes from Thamusida (Morocco): grouping natron-based blue-green and colourless Roman glasses. Archaeometry 55:609-639

Goldstein S, Lindgren S (2005) Small artefacts other than pottery. The glass finds. In: Stevens ST, Kalinowski AV, Leest H (eds) Bir 
Ftouha: a pilgrimage church complex at Carthage. Journal of Roman Archaeology Supplementary Series 59:431-449

Gorin-Rosen Y (1995) Hadera, Bet Eli'ezer. Excavations and Surveys in Israel 13:42-43

Gorin-Rosen Y (2000) The ancient glass industry in Israel - summary of the finds and new discoveries. In: Nenna M-D (ed) La route du verre. Ateliers primaires et secondaires du second millénaire av. J.C. au Moyen Âge. Maison de 1'Orient Méditerranéen-Jean Pouilloux, Lyon, pp 49-63

Gratuze B, Barrandon JN (1990) Islamic glass weights and stampsanalysis using nuclear techniques. Archaeometry 32:155-162

Greiff S, Hartmann S (2013) "Wer kriegt was?": Untersuchungen zur Verbreitung spätantiker und frühmittelalterlicher Glasgruppen in Europa und dem Mediterraneum anhand von Fallbeispielen. In: Hauptmann A, Mecking O, Prange M (eds) Archäometrie und Denkmalpflege 2013. Deutsches Bergbau-Museum, Bochum, pp 251-255

Hayes JW (1993) The glass finds. In: Stevens ST (ed) Bir El Knissia at Carthage: a rediscovered cemetery church. Report No. 1. Journal of Roman Archaeology Supplementary Series 7:289-294

Henderson J (2013) Glass: an interdisciplinary exploration. Cambridge University Press, Cambridge

Hurst HR (2010) Understanding Carthage as a Roman port, meetings between cultures in the ancient Mediterranean. Proceedings of the 17th International Congress of Classical Archaeology, Rome 2008. Bollettino di Archaeologia online, pp 49-68

Jackson CM (2005) Making colourless glass in the Roman period. Archaeometry 47:763-780

Jackson CM, Joyner L, Booth CA, Day PM, Wager ECW, Kilikoglou V (2003) Roman glass-making at Coppergate, York? Analytical evidence for the nature of production. Archaeometry 45:435-456

Jackson CM, Paynter S (2015) A great big melting pot: exploring patterns of glass supply, consumption and recycling in Roman Coppergate, York. Archaeometry. doi:10.1111/arcm.12158

Longacre WA (1999) Standardization and specialization: what's the link?'. In: Skibo JM, Feinman GM (eds) Pottery and people: a dynamic interaction. University of Utah Press, Salt Lake City, pp 44 58

Maltoni S, Chinni T, Vandini M, Cirelli E, Silvestri A, Molin G (2015) Archaeological and archaeometric study of the glass finds from the ancient harbour of Classe (Ravenna-Italy): new evidence. Heritage Science 3:13

Merrills A, Miles R (2010) The Vandals. Blackwell Publishing, Chichester

Mirti P, Lepora A, Sagui L (2000) Scientific analysis of seventh-century glass fragments from the Crypta Balbi in Rome. Archaeometry 42: 359-374

Nenna M-D (2014) Egyptian glass abroad. HIMT glass and its markets. In: Bayley J, Jackson C, Keller D, Price J (eds) Neighbours and successors of Rome. Traditions of glass production in use in Europe and the Middle East in the later first millennium AD. Oxbow Books, Oxford, pp 178-193

Nenna M-D (2015) Primary glass workshops in Graeco-Roman Egypt: preliminary report on the excavations of the site of Beni Salama, Wadi Natrun (2003, 2005-9). In: Bayley J, Freestone I, Jackson C (eds) Glass of the Roman World. Oxbow Books, Oxford, pp 1-22

Norman NJ (2002) Death and burial of Roman children: the case of the Yasmina cemetery at Carthage, part I, setting the stage. Mortality 7: 302-323

Norman NJ (2003) Death and burial of Roman children: the case of the Yasmina cemetery at Carthage, part II, the archaeological evidence. Mortality 8:36-47

Norman NJ, Haeckl AE (1993) The Yasmina necropolis at Carthage. Journal of Roman Archaeology 6:238-250
Paynter S (2008) Experiments in the reconstruction of Roman wood-fired glassworking furnaces: waste products and their formation processes. Journal of Glass Studies 50:271-290

Picon M, Vichy M (2003) D'Orient en Occident: l'origine du verre à l'époque romaine et durant le haute Moyen Åge. In: Foy D, Nenna M-D (eds) É changes et commerce du verre dans le monde antique : actes du colloque de l'Association française pour l'archéologie du verre. Aix-en-Provence et Marseille, 7-9 juin 2001, Éditions Monique Mergoil, Montagnac, pp 17-31

Price J, Freestone IC, Cartwright CRC (2005) 'All in a day's work?' The colourless cylindrical glass cups found at Stonea revisited. In: Crummy N (ed) Image, craft and the classical world: essays in honour of Donald Bailey and Catherine Johns. Monographies Instrumentum no. 29, Montagnac, pp 163-169

Procopius (1916) History of the Wars, Vol.2, Books 3-4. Translated by H.B. Dewing. Loeb Classical Library. Harvard University Press, Cambridge MA

Rehren T, Marii F, Schibille N, Stanford L, Swan C (2010) Glass supply and circulation in Early Byzantine Southern Jordan. In: Drauscke J, Keller D (eds) Glass in Byzantium - production, usage, analyses. RGZM, Mainz, pp 65-82

Rehren T, Brüggler M (2015) Composition and production of late antique glass bowls type Helle. Journal of Archaeological Science: Reports 3:171-180

Rosenow D, Rehren T (2014) Herding cats: Roman to late antique glass groups from Bubastis, northern Egypt. J Archaeol Sci 49:170-184

Sarris P (2011) Empires of faith: the fall of Rome to the Rise of Islam, 500-700. Oxford University Press, Oxford

Schibille N (2011) Supply routes and the consumption of glass in first millennium CE Butrint (Albania). Journal of Archaeological Science 38:2939-2948

Schibille N, Degryse P, Corremans M, Specht CG (2012) Chemical characterisation of glass mosaic tesserae from sixth-century Sagalassos (south-west Turkey): chronology and production techniques. Journal of Archaeological Science 39:1480-1492

Schibille N, Freestone IC (2013) Composition, production and procurement of glass at San Vincenzo al Volturno: an early medieval monastic complex in Southern Italy. Plos One 8(10), e76479. doi:10. 1371/journal.pone.0076479136

Schmidt K (2007) Kleinfunde: Schmuckstein (Gemme), Glas, Fayence, Straußenei. In: Niemeyer HG, Docter RF, Schmidt K, Bechtold B (eds) Karthago. Die Ergebnisse der Hamburger Grabung unter dem Decumanus Maximus (Hamburger Forschungen zur Archäologie 2). Philipp von Zabern, Mainz, pp 777-784

Shepherd J (2015) A Gazeteer of glass-working sites in Roman London. In: Bayley J, Freestone I, Jackson C (eds) Glass of the Roman world. Oxbow, Oxford, pp 33-43

Silvestri A (2008) The coloured glass of Iulia Felix. Journal of Archaeological Science 35:1489-1501

Silvestri A, Molin G, Salviulo G (2008) The colourless glass of Iulia Felix. Journal of Archaeological Science 35:331-341

Sterrett-Krause AE (2006) Evidence for glass production from the Yasmina necropolis of Carthage, University of Cincinnati (MA thesis). https://etd.ohiolink.edu/!etd.send_file?accession= ucin1147276909\&disposition=inline

Sterrett-Krause AE (2009) Evidence for glass working from the Yasmina necropolis at Carthage. Annales $17 \mathrm{e}$ Congrès de l'Association Internationale pour l'Histoire du Verre, pp 240-246

Tal O, Jackson-Tal RE, Freestone IC (2004) New evidence of the production of raw glass at late Byzantine Apollonia-Arsuf, Israel. Journal of Glass Studies 46:51-66

Tal O, Jackson-Tal RE, Freestone IC (2008) Glass from a late Byzantine secondary workshop at Ramla (South), Israel. J Glass Stud 50:8195

Tatton-Brown VA (1984) The glass. In: Hurst HR, Roskams SP (eds) Excavations at Carthage: the British mission, vol. I,1. The avenue 
du president Habib Bourguiba, Salammbo: the site and finds other than potter. The British Academy, Sheffield, pp 194-212

Tatton-Brown VA (1994) The glass. In: Hurst, HR (ed) Excavations at Carthage: the British mission, vol. II, 1. The circular harbour, north side. The site and finds other than pottery. Oxford University Press, Oxford, pp 282-290

Thirion-Merle V, Nenna M-D, Picon M, Vichy M (2003) Un nouvel atelier primaire dans le Wadi Natrun (Égypte), et les compositions des verres produits dans cette region. Bulletin de l'Association Française pour l'Archéologie du verre, pp 21-24

Velde B (1990) Alumina and calcium oxide contents of glass found in western and northern Europe, first to ninth centuries. Oxford Journal of Archaeology 9:105-117

Vincenzi E, Eggins S, Logan A, Wysoczanski R (2002) Microbeam characterization of Corning archaeological reference glasses: new additions to the Smithsonian Microbeam Standard Collection. Journal of Research of the National Institute of Standards and Technology 107: 719-727 von Rummel P (2011) Settlement and taxes: the Vandals in North Africa. In: Díaz PC, Viso IM (eds) Between taxation and rent: fiscal problems from late antiquity to early middle ages/Entre el impuesto y la renta: Problemas de la fiscalidad tardoantigua y altomedieval. Edipuglia, Bari, pp 23-37

Wagner B, Nowak A, Bulska E, Hametner K, Günther D (2012) Critical assessment of the elemental composition of Corning archaeological reference glasses by LA-ICP-MS. Analytical and bioanalytical chemistry 402:1667-1677

Wedepohl KH, Pirling R, Hartmann G (1997) Römische und fränkische Gläser aus dem Gräberfeld von Krefeld-Gellep. Bonner Jahrbücher 197:177-189

Whitehouse D (2004) Glass in the price edict of Diocletian. Journal of Glass Studies 46:189-191

Wickham C (2005) Framing the early Middle Ages: Europe and the Mediterranean 400-800. Oxford University Press, Oxford 